\title{
Preparation and evaluation of free gluten bakery products by using germinated quinoa.
}

\author{
Mona, M. M. Doweidar ${ }^{1}$; Thanaa, A. M. Amer ${ }^{1}$; Fatma, M. I. Shahine ${ }^{1}$ and A. S. Shams ${ }^{2}$ \\ ${ }^{1}$ Bread \& Pastries Dept., Food Technol. Research Instit., Agric. Research Center, Giza. \\ ${ }^{2}$ Crop Intensification Research Dept., Field Crops Research Instit., Agric. Research Center, Giza.
}

\begin{abstract}
The aim of this study is to enhance gluten-free bakery products by using germinated quinoa in order to create the best suitable product with baked and sensory characteristics similar to those of wheat flour for celiac disease. The rice flour which usually used in such baked was replaced by using, germinated quinoa flour at replacement levels $(25,50$ and $75 \%)$ with using mixture of potato puree, corn starch a constant level of formula compared to the control sample for production gluten-free bakery products (i.e. date bars pies, cracker and biscuit).All produced products were evaluated chemically, organolyptically, physically and economically. The obtained data showed that by increasing the substation levels of germinated quinoa in gluten-free bakery products formulas were increase the protein, fat, ash, dietary fiber, minerals content (i.e., Iron, zinc, calcium , magnesium , potassium, cupper and phosphors), vitamins contents( i.e., Thiamin $\mathrm{B}_{1}$, Riboflavin $\mathrm{B}_{2}$, Foliate $\mathrm{B}_{9}$, $\mathrm{A}$ and $\mathrm{E})$. This must be due to the higher contents of these components in germinated quinoa flour compared to the used rice flour with mixture of potato puree and corn starch. On the other hand a slight decrease occurred in the content of carbohydrates and calories in previous bakery products compared with the control. Gluten free date bars pies and biscuit had acceptance (very good) at substitution levels 25 and $50 \%$, while at $75 \%$ had less acceptance (good). Cracker had acceptance (very good) at substitution level 75\%. Physical evaluation showed that, specific volume slight decreased by increasing substitution levels of germinated quinoa flour in all glutenfree bakery products. All previous products showed a slight increase in the values of both the moisture and weight compared with the control. All the previous types of bakery products supplemented with germinated quinoa flour were the highest in contribute of most of Recommended Dietary Allowances for protein, dietary fiber, mineral (i.e., iron, zinc, calcium and magnesium, potassium, cupper and phosphors) and vitamins for children and adults. The cost was increased with rate 0.33 to $21.18 \%$. The result of this study recommended the integration of germinated quinoa flour with rice flour for the manufacturing of high nutritional value of glutenfree bakery product for celiac disease.
\end{abstract}

Keywords: gluten-free bakery products, germinated quinoa flour, rice flour, potato puree, corn starch,

\section{Introduction}

There has been a progressive increase in the number of patients diagnosedwith coeliac disease in the past few decades (Gallagher, 2009). It is believed that the disease has already accounted for almost $1 \%$ of the world population (Catassi and Yachha, 2009). People suffering from coeliac disease react with inflammation of the small intestine, leading to malabsorption of several important nutrients including iron, foliate, calcium and fat soluble vitamins (Feighery, 1999 and Murray, 1999). Coeliac disease is caused by a reaction to gliadin, a prolamin (i.e., gluten protein) found in wheat. Upon exposure to gliadin, and specifically to peptides found in prolamin, the enzyme tissue transglutaminase modifies the protein, and the immune system cross-reacts with the small bowel tissue, causing an inflammatory reaction Moore et al., (2006). That leads to villous atrophy, which interferes with the absorption of nutrients, namely vitamins and minerals (Pite, 2008). Clinical and epidemiological studies have showed coeliac disease to be a risk factor for cancer (Silanoet al., 2007), osteoporosis (Sategna-Guidettiet al., 2000), thyroid disease (Sategna-Guidettiet al., 1998), female infertility (Stazi and Mantovani, 2000), neurological and psychiatric disorders (Ludvigsson et al., 2007 and Tengah et al., 2002). Therefore a strict gluten-free diet - without cereals containing gluten proteins (wheat, barley, rye, triticale, dinkel and kamut) is essential (Gallagher $\boldsymbol{e t}$ al., 2009). Such a diet improves the health-related quality of life in terms of less symptoms of the disease and normalized microvilli, which is of utmost importance for optimal gastrointestinal functions (Johnston $\boldsymbol{e t}$ al., 2004). As such, it is very important to continuously develop gluten-free food products to meet with such rapidly growing demands. Glutenfree starchy materials, such as maize, rice and potato, are usually used in the manufacturing of bread, pasta, biscuits, and textured using different combinations of thickenings (guar gums, carboxymethyl cellulose and carob flour), and particular food processing procedures different from the conventional ones (Thompson, 1999). As a result, many gluten-free cereal foods do not contain the same levels of Bvitamins, iron and fiber as their gluten-containing counterparts (Thompson, 1999 and Thompson, 2000). Quinoa is a safe choice for the production of gluten-free products (Valencia-Chamorro ,2003 ., 2004). Unlike most grains, quinoa contains a 
complete protein. It is high in essential amino acids and fatty acids and it's a good source of vitamin C, E and several of the $\mathrm{B}$ vitamins (Jancurova et al.,2009). This makes it especially good as a grain substitute in gluten free diets as most people get the majority of their B vitamins from baked goods. Quinoa contains between 14 and 18\% protein, with characteristics similar to milk protein. Quinoa is also a source of calcium, magnesium, zinc and iron(Ranhotraetal., 1993 andPenarrieta, et al., 2008). A need to improve the nutritional quality of gluten-free cereal foods has been raised by many medical and nutritional experts (Kupper, 2005 and Thompson et al., 2005). The quinoa seed was characterized by an excellent nutrient profile. Besides being important energy sources due to their starch content, quinoa provide good-quality protein, dietary fiber and lipids rich in unsaturated fats (Penarrietaet al., 2008 and Alvarez - Jubeteet al., 2009 a). Moreover, they contain adequate levels of important micronutrients, such as minerals and vitamins and significant amounts of other bioactive components, such as saponins, phytosterols, squalene, fagopyritols and polyphenols. In a series of recent studies, the nutritional properties and baking characteristics of amaranth, quinoa and buckwheat have been assessed (Alvarez-Jubeteet al., 2009 a.; Alvarez-Jubeteet al., 2009b and Alvarez-Jubeteet al., 2010). The authors found that the replacement of potato starch with a pseudo cereal(amaranth, quinoa and buckwheat) flour resulted in gluten-free breads with an increased content of important nutrients, such as protein, fiber, calcium, iron and vitamin E. The resulting breads also had a significantly higher content of polyphenol compounds and their in vitro antioxidant activity was increased. Furthermore quinoa is rich in omega -3 , and essential amino acids, lysine, methionine and cystine(Alvarez-Jubeteet al., 2009a andHareedyLobnaet al., 2009), whereas corn and rice lesser contents of the aforementioned compounds. Germinated were utilized to increase protein content, nutritional characteristics and bioactive compounds content of certain food (Maraoet al., 1988 and Valencia et al., 1999).Germination of cereals/pseudo-cereals has been suggested as an inexpensive and effective method to enhance the antioxidant capacity through the increase of low-molecular weight antioxidants. Besides, an increase in bioavailability of essential minerals and a higher content of vit. B complex (Alvarez-Jubeteet al., 2010).

This study was carried out to impact of germinated quinoa flour at different levels on chemically, organoleptically, physically and nutritional of some glutenfree bakery products (date bars pies, cracker and biscuit).

\section{Materials and Methods}

Materials:-
- Corn starch (Zea maize L.) flour was obtained from Egyptian-Italian Company for maize products (Maiza), $10^{\text {th }}$ of Ramadan City, Cairo, Egypt.)

- White rice flour (Oryza sativa L.) was obtained from Sky Live for Company. for Food Industry, Giza, Egypt.)

- Quinoa seeds (Chenopodium quinoa Willd.), variety Titicaca was obtained from Crop Intensification Research Department (CIRD), Field Crops Research Institute (FCRI), Agricultural Research Center (ARC) Giza, Egyptas a novel crop for agriculture in Egypt. Quinoa seeds was planted in sandy soil at Ismailia Agricultural Research Station in 2010/2011 and 2011/2012 seasons and the quinoa grain yield ranged from 1.722 to 2.139 ton/hectares in the first and second seasons, respectively.

- Potato (SolanumtuberosumL.) was obtained from Horticultural Research Institute, Agriculture Research Center (Giza, Egypt).

- Xanthan gum was obtained from Egyptian International Trade Company, SadaZanb, Giza, Egypt

- All other materials used in making bakery products i.e. sugar powder, skim milk, improver, butter, corn oil, baking powder, baking soda, eggs and vanilla were obtained from local market in Dokki, Giza Governorate,Egypt.

\section{Methods:- \\ Preparation of germinatedquinoa flour:}

Quinoa seeds were cleaned and washed several times with running tap water (with constant stirring for about 1-2 $\mathrm{min}$ ) to get rid of the foam, and soaking in water $(1: 3 \mathrm{w} / \mathrm{v})$ for 30 hours in darkness (Soaking water is renewed during this period). The water was drained off and the wet seeds transferred to moistened cotton layers and allowed to germinate for 36 hours in darkness at room temperature (20$24^{\circ} \mathrm{C}$ ), and watered 3 times during this period. The sprouts of seeds were dried in an air oven at $55^{\circ} \mathrm{C}$. The dried sprouts was milled to a fine powder, and then sieved on a100 $\mu \mathrm{m}$. sieve, as according to Valencia et al., (1999). Finegerminatedquinoa flour (whole meal) was packaged into polyethylene bags and stored in deep freezer $\left(-18^{\circ} \mathrm{C}\right)$ until using.

\section{Preparation of potatoespuree:}

Potato were washed then boiled in little water for about $30 \mathrm{~min}$,thenhandpeeled and pureed in homogenizer for using in the preparing free gluten bakery.

Procedure

a. Preparation of date bars pies:-

Pies were prepared according to the method described in AACC (2002) with some modification in the formula.

The blends and basic formulations used for preparation of controlandgluten-free date bars pies products were presented in Table (1). 
Table 1. Glutenfree date bars pies (GFDP) blends.

\begin{tabular}{lcccccc}
\hline \multicolumn{1}{c}{ Ingredients (gm) } & Control & \multicolumn{7}{c}{ GFDP blends } \\
\cline { 2 - 7 } & & $\mathbf{1}$ & $\mathbf{2}$ & $\mathbf{3}$ & $\mathbf{4}$ & $\mathbf{5}$ \\
\hline Wheat flour (72\%ext.) & $\mathbf{1 0 0}$ & - & - & - & - & - \\
* Potato puree & - & $\mathbf{2 0}$ & $\mathbf{2 0}$ & $\mathbf{2 0}$ & $\mathbf{2 0}$ & $\mathbf{2 0}$ \\
Corn starch & - & $\mathbf{5}$ & $\mathbf{5}$ & $\mathbf{3 0}$ & $\mathbf{5}$ & $\mathbf{5}$ \\
White rice flour & - & $\mathbf{7 5}$ & - & $\mathbf{2 5}$ & $\mathbf{2 5}$ & $\mathbf{5 0}$ \\
Quinoa flour & - & - & $\mathbf{7 5}$ & $\mathbf{2 5}$ & $\mathbf{5 0}$ & $\mathbf{2 5}$ \\
Butter & 4 & 4 & 4 & 4 & 4 & 4 \\
Corn oil & 4 & 4 & 4 & 4 & 4 & 4 \\
Sugar powder & 15 & 15 & 15 & 15 & 15 & 15 \\
Eggs (whole fresh) & 7.5 & 7.5 & 7.5 & 7.5 & 7.5 & 7.5 \\
Baking powder & 0.5 & 0.5 & 0.5 & 0.5 & 0.5 & 0.5 \\
Baking soda & 0.5 & 0.5 & 0.5 & 0.5 & 0.5 & 0.5 \\
Skim milk powder & 0.5 & 0.5 & 0.5 & 0.5 & 0.5 & 0.5 \\
Xanthan gum & - & 1 & 1 & 1 & 1 & 1 \\
Vanilla & 0.3 & 0.3 & 0.3 & 0.3 & 0.3 & 0.3 \\
Improver & 1 & 1 & 1 & 1 & 1 & 1 \\
Water (ml & As & As & As & As & As & As \\
& required & required & required & required & required & required \\
\hline Date & 50 & 50 & 50 & 50 & 50 & 50 \\
\hline Nat- Presyyyyyyy
\end{tabular}

Note: - Pretest experiment has been carried out to determine the best mixes ratio of suggested materials for this study.

* Potato puree was added on dry weight basis (puree potato contain $80 \%$ moisture).

For makingpies, all dry ingredients were mixed together in a dough mixer for 3 minutes, then all liquid ingredients were added to the dry mixture and mixed at low speed for 5 minutes and then sufficient warm water amount were added to bring dough to a desired standard consistency after mixing. The resulted dough was let to rest for 15 mints. The dough wassheeted into $2.0 \mathrm{~mm}$ and shaped into a rectangle about $40 \times 4 \mathrm{Cm}$. Spread date filling evenly down the center and out toward the edges of the dough, allowing $0.5 \mathrm{Cm}$. of the edges for sealing. Roll the remaining dough into a same-size rectangle. Roll it onto the rolling pin and unroll it directly over the dates. Press gently to seal edges, cut into bars 4 x 3.5 $\mathrm{Cm}$.Bars pies were arranged on a baking tray and placed in a fermentation cabinet for about $40 \mathrm{~min}$. at $37^{\circ} \mathrm{C}$ and $85 \%$ relative humidity. After proofing the bars pies were baked at $200^{\circ} \mathrm{C}$ for $15 \mathrm{~min}$. After baking, parspies were allowed to cool at room temperature for $1 \mathrm{hr}$. before organoleptic evaluation.

\section{b.Preparation of crackers:-}

Crackers were made according to the methods described in Bose and Shams-Ud-Din (2010). The blends and basic formulations used for preparation of controlandgluten-free crackers are outlined in Table(2).

The pre weighted ingredients were mixed. Fat was added into the dry ingredients. Water was added accurately to form smooth dough, and the resulted dough was let to rest for $5 \mathrm{~min}$. The dough kneaded and rolled to a uniform thickness of $3 \mathrm{~mm}$. The crackers were cut out. Then the crackers were baked at $200^{\circ} \mathrm{C}$ for $10-15$ minutes and cooled at room temperature for about $1 \mathrm{hr}$. before sensory evaluation.

\section{Preparation of biscuits:}

Biscuit was made according to the standard procedure for sweet biscuit at BiscoMisrCo., Cairo. The blends and formula of control and other suggestion formula to made gluten-free biscuits were found in Table (3).

All dry ingredients were mixed together in a dough mixer for 3 minutes, then all liquid ingredients were added to the dry mixture and mixed at low speed for 3 minutes then water added as require to obtained suitable smooth dough, and the resulted dough was let to rest for $5 \mathrm{~min}$. Then sheeted to $3 \mathrm{~mm}$. thickness. Circle pieces cut of dough were formed by using of templates with an outer diameter of $50 \mathrm{~mm}$. The biscuits were baked at $180^{\circ} \mathrm{C}$ for 12 mins, and allowed to cool at room temperature for 1 $\mathrm{hr}$. before sensory evaluation.

\section{Chemical analysis:}

Moisture, protein, ash contents and ether extract were determined according to the methods described byA.O.A.C. (2005). Dietary fiber was determined according to the method described by Proskyet al. (1984). Digestible carbohydrates (D.C) were calculated by difference according to the following equation:

D. $C=100-(\%$ moisture $+\%$ protein $+\%$ total lipid + $\%$ ash $+\%$ fiber $)$.

Caloric value was calculated according to the following equation (FAO/WHO, 1974):

Caloric value $=4($ protein $\%+$ Carbohydrate $\%)+9$ (fat \%).

Minerals content, i.e., $\mathrm{Fe}, \mathrm{Zn}, \mathrm{Ca}, \mathrm{Mg}, \mathrm{K}, \mathrm{Cu}$ and $\mathrm{P}$ were determined by atomic absorption spectrophotometer (3300 Perkin-Elmer) as described in A.O.A.C. (2005). 
Vitamins content: vitamin $\mathrm{E}$, vitamin $\mathrm{A}$ and vitamin $\mathrm{B}$ group $\left(\mathrm{B}_{1}, \mathrm{~B}_{2}, \mathrm{~B}_{3}, \mathrm{~B}_{6}\right.$, and $\left.\mathrm{B}_{9}\right)$ were determined according to the methods described by Pyka and
Sliwiok (2001), Noll (1996) and Batifoulieret al., (2005) respectively.

Table 2.Glutenfree cracker (GFC) blends.

\begin{tabular}{|c|c|c|c|c|c|c|}
\hline \multirow{2}{*}{ Ingredient (gm) } & \multirow{2}{*}{ Control } & \multicolumn{5}{|c|}{ GFC blends } \\
\hline & & 1 & 2 & 3 & 4 & 5 \\
\hline Wheat flour (72\%ext.) & 100 & - & - & - & - & - \\
\hline * Potato puree & - & 20 & 20 & 20 & 20 & 20 \\
\hline Corn starch & - & 5 & 5 & 30 & 5 & 5 \\
\hline White rice flour & - & 75 & - & 25 & 25 & 50 \\
\hline Quinoa flour & - & - & 75 & 25 & 50 & 25 \\
\hline Butter & 5 & 5 & 5 & 5 & 5 & 5 \\
\hline Corn oil & 5 & 5 & 5 & 5 & 5 & 5 \\
\hline Baking powder & 0.5 & 0.5 & 0.5 & 0.5 & 0.5 & 0.5 \\
\hline Baking soda & 0.5 & 0.5 & 0.5 & 0.5 & 0.5 & 0.5 \\
\hline Skim milk powder & 1 & 1 & 1 & 1 & 1 & 1 \\
\hline Xanthan gum & - & 1 & 1 & 1 & 1 & 1 \\
\hline Salt & 2 & 2 & 2 & 2 & 2 & 2 \\
\hline Improver & 1 & 1 & 1 & 1 & 1 & 1 \\
\hline Citric acid & 0.4 & 0.4 & 0.4 & 0.4 & 0.4 & 0.4 \\
\hline Sauce & 0.2 & 0.2 & 0.2 & 0.2 & 0.2 & 0.2 \\
\hline Water $\left(\mathrm{ml}^{3}\right)$ & $\begin{array}{c}\text { As } \\
\text { required }\end{array}$ & $\begin{array}{c}\text { As } \\
\text { required }\end{array}$ & $\begin{array}{c}\text { As } \\
\text { required }\end{array}$ & $\begin{array}{c}\text { As } \\
\text { required }\end{array}$ & $\begin{array}{c}\text { As } \\
\text { required }\end{array}$ & $\begin{array}{c}\text { As } \\
\text { require }\end{array}$ \\
\hline
\end{tabular}

Note: - Pretest experiment has been carried out to determine the best mixes ratio of suggestedmaterials for this study.

* Potatopuree was addedon dry weight basis (puree potato contain $80 \%$ moisture).

Table 3.Glutenfreebiscuit (GFB)blends.

\begin{tabular}{|c|c|c|c|c|c|c|}
\hline \multirow[t]{2}{*}{ Ingredient (gm) } & \multirow[t]{2}{*}{ Control } & \multicolumn{5}{|c|}{ GFBblends } \\
\hline & & 1 & 2 & 3 & 4 & 5 \\
\hline Wheat flour (72\% ext.) & 100 & - & - & - & - & - \\
\hline * Potatopuree & - & 10 & 10 & 10 & 10 & 10 \\
\hline Corn starch & - & 15 & 15 & 40 & 15 & 15 \\
\hline White rice flour & - & 75 & - & 25 & 25 & 50 \\
\hline Quinoa flour & - & - & 75 & 25 & 50 & 25 \\
\hline Butter & 10 & 10 & 10 & 10 & 10 & 10 \\
\hline Corn oil & 16 & 16 & 16 & 16 & 16 & 16 \\
\hline Sugar (powder) & 50 & 50 & 50 & 50 & 50 & 50 \\
\hline Eggs (whole fresh) & 10 & 10 & 10 & 10 & 10 & 10 \\
\hline Baking powder & 3 & 3 & 3 & 3 & 3 & 3 \\
\hline Skim milk powder & 4 & 4 & 4 & 4 & 4 & 4 \\
\hline Xanthan gum & - & 1.5 & 1.5 & 1.5 & 1.5 & 1.5 \\
\hline Vanilla & 1 & 1 & 1 & 1 & 1 & 1 \\
\hline Improver & 1 & 1 & 1 & 1 & 1 & 1 \\
\hline Water $\left(\mathrm{ml}^{3}\right)$ & $\begin{array}{c}\text { As } \\
\text { required }\end{array}$ & $\begin{array}{c}\text { As } \\
\text { required }\end{array}$ & $\begin{array}{c}\text { As } \\
\text { required }\end{array}$ & $\begin{array}{c}\text { As } \\
\text { required }\end{array}$ & $\begin{array}{c}\text { As } \\
\text { required }\end{array}$ & $\begin{array}{c}\text { As } \\
\text { required }\end{array}$ \\
\hline
\end{tabular}

Note: - Pretest experiment has been carried out to determine the best mixes ratio of suggested materials for this study.

* Potatopuree was addedon dry weight basis (puree potato contain $80 \%$ moisture).

\section{Sensory evaluation of pies:}

Date bars pies, crackers and biscuits produced using suggested blends were evaluated for their sensory characteristics by ten panelists from the staff of Bread and Pastry, Research Dep.,Food Tech. Res. Institute., Agr. Res. Center, Giza. The scoring scheme was established as described in A.A.C.C. (2002), with some modification.

\section{Physical properties:}

Physical properties of produced samples were determined according to A.A.C.C. (2002). Biscuit diameter (D) and thickness (T) were measured for groups of 10 biscuit.The spread ratio obtained was the ratio between diameter (D) and thickness (T). Volume $\left(\mathrm{Cm}^{3}\right)$ of produced samples were determined by the displacement of rape seeds, specific volume was calculated as the ratio between the volume of the cooled baked biscuit, and their weight. 


\section{Statistical analysis:}

The data obtained from sensory evaluations were statistically analyzed by the least significant differences value (L.S.D) at 0.05 levels probability procedure to Snedecor and Cochran (1967).

\section{Results and Discussion}

\section{Chemical composition of raw materials:}

The obtained results in table (4) indicated that germinated quinoa flour contained the highest values of protein, fat, dietary fiber and ash (15.23, $3.99,7.89$ and $3.79 \%$, respectively), whereas it was showed the lowest value indigestible carbohydrates $(69.10 \%)$ compared with wheat flour (72\% ext.), potatopuree, corn starch and white rice. On the contrary, corn starch contained the lowest value of protein $(0.38 \%)$, fat $(0.16 \%)$, dietary fiber $(0.98 \%)$ and ash $(0.10 \%)$, while it showed the highest values of digestible carbohydrate $(98.38 \%)$.

Table 4. Chemical composition of raw materials $(\mathrm{g} / 100 \mathrm{~g}$ sampleon dry weight basis).

\begin{tabular}{|c|c|c|c|c|c|}
\hline Component & $\begin{array}{l}\text { Wheat flour } \\
72 \% \text { ext. }\end{array}$ & $\begin{array}{l}\text { Potato } \\
\text { puree }\end{array}$ & $\begin{array}{l}\text { Corn } \\
\text { starch }\end{array}$ & White rice flour & $\begin{array}{c}\text { Germinated quinoa } \\
\text { flour } \\
\text { (Whole meal) }\end{array}$ \\
\hline Moisture & 11.92 & 80.0 & 8.32 & 11.85 & 9.98 \\
\hline Protein & 11.73 & 7.59 & 0.38 & 7.15 & 15.23 \\
\hline Fat & 1.11 & 0.44 & 0.16 & 0.92 & 3.99 \\
\hline Dietary fiber & 3.07 & 6.99 & 0.98 & 2.72 & 7.89 \\
\hline Ash & 0.45 & 0.49 & 0.10 & 0.41 & 3.79 \\
\hline *Digestible & 83.64 & 84.49 & 98.38 & 88.80 & 69.10 \\
\hline \multicolumn{6}{|c|}{ Minerals content $\mathrm{mg} / 100 \mathrm{gm}$} \\
\hline $\mathrm{Fe}$ & 1.33 & 1.38 & 0.51 & 0.40 & 16.13 \\
\hline $\mathrm{Zn}$ & 0.79 & 1.20 & 0.07 & 0.91 & 6.34 \\
\hline $\mathrm{Ca}$ & 17.03 & 35.49 & 2.18 & 11.35 & 108.12 \\
\hline $\mathrm{Mg}$ & 24.98 & 88.73 & 3.27 & 39.72 & 197.74 \\
\hline $\mathrm{K}$ & 121.5 & 955.0 & 3.27 & 86.26 & 826.7 \\
\hline $\mathrm{Cu}$ & 0.16 & 0.741 & 0.06 & 0.148 & 5.1 \\
\hline $\mathrm{P}$ & 122.62 & 177.46 & 14.18 & 111.22 & 383.7 \\
\hline \multicolumn{6}{|c|}{ Vitamins content } \\
\hline $\begin{array}{l}\text { Thiamin }\left(\mathrm{B}_{1}\right) \\
(\mathrm{mg} / 100 \mathrm{gm}\end{array}$ & 0.136 & 0.425 & - & 0.157 & 0.43 \\
\hline $\begin{array}{c}\text { Riboflavin }\left(\mathrm{B}_{2}\right) \\
(\mathrm{mg} / 100 \mathrm{gm})\end{array}$ & 0.045 & 0.084 & - & 0.023 & 0.39 \\
\hline $\begin{array}{l}\text { Niacin }\left(B_{3}\right) \\
(\mathrm{mg} / 100 \mathrm{gm})\end{array}$ & 1.42 & 5.82 & - & 2.94 & 1.52 \\
\hline $\mathrm{B}_{6}(\mathrm{mg} / 100 \mathrm{gm})$ & 0.05 & 1.19 & - & 0.49 & 0.49 \\
\hline $\begin{array}{l}\text { Folate }\left(\mathrm{B}_{9}\right) \\
(\mu \mathrm{g} / 100 \mathrm{gm})\end{array}$ & 29.52 & 39.49 & - & 4.54 & 194.0 \\
\hline $\mathrm{A}(\mu \mathrm{g} / 100 \mathrm{gm})$ & - & - & - & - & 32.5 \\
\hline $\mathrm{E}(\mathrm{mg} / 100 \mathrm{gm})$ & 0.068 & 0.222 & - & 0.148 & 2.44 \\
\hline
\end{tabular}

From the same table, it can be seen that, germinated quinoa flour had the highest value of $\mathrm{Fe}, \mathrm{Zn}, \mathrm{Ca}, \mathrm{Mg}$, $\mathrm{Cu}$ and $\mathrm{P}(16.13,6.34,108.12,197.74,5.10$ and $383.70 \mathrm{mg} / 100 \mathrm{gm}$, respectively.), whereas wheat flour $(72 \%$ ext.), potato puree, corn starch and white ricewerelower contents of the aforementioned mineral.Potatopureehad the highest value of K (955.0 $\mathrm{mg} / 100 \mathrm{gm})$. The results also indicated that germinated quinoa flour contained the highest values of vitamins contents i.e., Thiamin $\left(\mathrm{B}_{1}\right)$, Riboflavin $\left(\mathrm{B}_{2}\right)$, Foliate $\left(\mathrm{B}_{9}\right), \mathrm{A}$ and $\mathrm{E}$ compared with otherusedofraw materials.Meanwhile, the potatopuree contained the highest values of vitamins niacin $\left(\mathrm{B}_{3}\right)$ andPyridoxin $\left(\mathrm{B}_{6}\right)$. The above mentioned results are in harmony with those obtained by Koziol (1992) , Konishiet al. (2004) and Jancurovaet al. (2009).

Germinated quinoa flour could be considered as a good fortifier and lead to enrichment of cereal products.

Chemical composition and caloric value of produced gluten free date bars pies (GFDP): roduced:

An adequate knowledge of the chemical composition of food is vital to the health, well-being and safety of the consumer. 
Data in Table (5) show that, all samples of GFDP containing quinoa flour had the highest value of protein, fat, ash contents and dietary fiber and lowest value of digestible carbohydrate and total energy compared with the GFDP1 sample. All samples ofGFDP (except the GFDP1) had protein content ranged from 5.68-8.63\%, fat 5.64-6.58\%, ash $1.84-2.64 \%$, dietary fiber $3.58-5.61 \%$, digestible carbohydrate 76.54-83.26\% and total energy 399.90406.52 K.cal, while the GFDP1sample had protein $5.59 \%$, fat $5.33 \%$, ash $1.51 \%$, dietary fiber $3.04 \%$, digestible carbohydrate $84.53 \%$ and total energy $408.45 \mathrm{~K}$.cal. The rate of decrease in total caloric for samples was ranged from 0.89 to $2.97 \%$ compared with the control sample.Also, data in the same tableshowed that the all samples ofGFDP which containing quinoa flour had the highest values in minerals content (i.e., Iron, zinc, calcium , magnesium potassium, cupper and phosphors)and vitamins contents i.e., Thiamin $\left(\mathrm{B}_{1}\right)$ Riboflavin $\left(\mathrm{B}_{2}\right)$, Pyridoxine $\left(\mathrm{B}_{6}\right)$, Foliate $\left(\mathrm{B}_{9}\right)$, A and E compared with the GFDP1 and control samples. Hence,GFDP samples containing quinoa flour are favorable than the GFDP1sample because of their high content of important minerals and vitamins which depend upon the quinoa flour levels of substitution. These results are confirmed with those obtained byJancurovaet al (2009),Leeet al(2009) and Doweidar-Monaand Kamel (2011).

Table 5.Chemical composition of produced glutenfree date bars pies (GFDP) (g/100g sample on dry weight basis).

\begin{tabular}{|c|c|c|c|c|c|c|}
\hline \multirow[b]{2}{*}{ Components \% } & \multirow{2}{*}{ Control } & \multicolumn{5}{|c|}{ GFDP blends } \\
\hline & & 1 & 2 & 3 & 4 & 5 \\
\hline Protein & 8.25 & 5.59 & 8.63 & 5.68 & 7.62 & 6.60 \\
\hline Fat & 5.52 & 5.33 & 6.58 & 5.64 & 6.16 & 5.75 \\
\hline Ash & 1.53 & 1.51 & 2.64 & 1.84 & 2.27 & 1.86 \\
\hline Dietary fiber & 2.34 & 3.04 & 5.61 & 3.58 & 4.71 & 3.82 \\
\hline * Digestible carbohydrate & 82.36 & 84.53 & 76.54 & 83.26 & 79.24 & 81.97 \\
\hline Caloric value (K.cal/100g) & 412.12 & 408.45 & 399.9 & 406.52 & 402.88 & 406.03 \\
\hline $\begin{array}{l}\text { Rate of decreased for } \\
\text { total caloric }\end{array}$ & - & 0.89 & 2.97 & 1.36 & 2.24 & 1.47 \\
\hline \multicolumn{7}{|c|}{ Mineral mg/100gm } \\
\hline $\mathrm{Fe}$ & 1.96 & 1.56 & 7.96 & 3.71 & 5.83 & 3.69 \\
\hline $\mathrm{Zn}$ & 0.57 & 0.64 & 2.85 & 1.26 & 2.11 & 1.38 \\
\hline $\mathrm{Ca}$ & 37.35 & 36.56 & 77.50 & 48.90 & 63.86 & 50.20 \\
\hline $\mathrm{Mg}$ & 24.04 & 36.29 & 100.59 & 52.76 & 79.16 & 57.70 \\
\hline $\mathrm{K}$ & 311.57 & 384.09 & 685.37 & 473.23 & 584.97 & 484.49 \\
\hline $\mathrm{Cu}$ & 0.21 & 0.27 & 2.29 & 0.92 & 1.61 & 0.94 \\
\hline $\mathrm{P}$ & 76.17 & 74.16 & 185.02 & 97.94 & 148.08 & 111.11 \\
\hline \multicolumn{7}{|c|}{ Vitamins content } \\
\hline Thiamin $\left(\mathrm{B}_{1}\right)(\mathrm{mg} / 100 \mathrm{gm}$ & 0.11 & 0.16 & 0.25 & 0.16 & 0.22 & 0.18 \\
\hline $\begin{array}{l}\text { Riboflavin }\left(B_{2}\right) \\
(\mathrm{mg} / 100 \mathrm{gm})\end{array}$ & 0.10 & 0.09 & 0.24 & 0.14 & 0.19 & 0.14 \\
\hline $\operatorname{Niacin}\left(B_{3}\right)(m g / 100 g m)$ & 1.48 & 2.53 & 1.96 & 1.95 & 2.15 & 2.35 \\
\hline Pyridexine $\left(\mathrm{B}_{6}\right)(\mathrm{mg} / 100 \mathrm{gm})$ & 0.03 & 0.33 & 0.33 & 0.26 & 0.33 & 0.33 \\
\hline Folate $\left(B_{9}\right)(\mu \mathrm{g} / 100 \mathrm{gm})$ & 17.14 & 7.16 & 80.19 & 30.88 & 55.85 & 31.50 \\
\hline $\mathrm{A}(\mu \mathrm{g} / 100 \mathrm{gm})$ & 26.96 & 26.90 & 40.18 & 31.37 & 35.78 & 31.38 \\
\hline $\mathrm{E}(\mathrm{mg} / 100 \mathrm{gm})$ & 0.04 & 0.62 & 1.02 & 0.37 & 0.70 & 0.39 \\
\hline
\end{tabular}

Sensory evaluation of produced gluten free date bars pies (GFDP):

Organoleptic tests are generally the final guide to the quality from the consumer's point of view.

Data in Table (6) and Fig(1) showed that there were no significant differences among control andGFDP1 and GFDP5samples for the general appearance and color. All samples of GFDP with control were the more acceptable (V.good) to the panelists, except GFDP2 sample which containing quinoa flour at level $75 \%$ had lowest acceptance (good).

Physical properties of produced gluten free date bars pies (GFDP):

Data in Table (7) show that the all samples of GFDP which containing quinoa had slight higher moisture content. It's ranged from 18.35 to $18.93 \%$ than the control (17.98\%) and GFDP 1 (18.31). Such increase in moisture may be due to the levels of substituted fiber. Data in Table (7) show that, heightand volume of the GFDP was more or less 
similar than the control sample. While; specific volume was slight decreased by increasing flour substitution from 25 to $75 \%$ for quinoa flour. The weights ofGFDP were slight increased by increasing flour substitution from 25 to $75 \%$ for quinoa flour. The increase of GFDP weights may be due to the increase water absorption by the higher level of quinoa flour.

Table6.Sensory evaluation of produced glutenfree date bars pies (GFDP).

\begin{tabular}{cccccccc}
\hline Treatment & $\begin{array}{c}\text { General } \\
\text { appearance } \\
(20)\end{array}$ & $\begin{array}{c}\text { Mastication } \\
(20)\end{array}$ & $\begin{array}{c}\text { Odor } \\
(20)\end{array}$ & $\begin{array}{c}\text { Taste } \\
(20)\end{array}$ & $\begin{array}{c}\text { Color } \\
(20)\end{array}$ & $\begin{array}{c}\text { Total score } \\
(100)\end{array}$ & Acceptance \\
\hline Control & $20.0^{\mathbf{a}}$ & $20.0^{\mathbf{a}}$ & $20.0^{\mathbf{a}}$ & $20.0^{\mathbf{a}}$ & $20.0^{\mathbf{a}}$ & $100.0^{\mathbf{a}}$ & $\mathrm{V}$ \\
GFDP1 & $20.0^{\mathbf{a}}$ & $19.0^{\mathbf{b}}$ & $20.0^{\mathbf{a}}$ & $19.0^{\mathbf{b}}$ & $20.0^{\mathbf{a}}$ & $98.0^{\mathbf{b}}$ & $\mathrm{V}$ \\
GFDP2 & $17.0^{\mathbf{c}}$ & $18.0^{\mathbf{c}}$ & $16.0^{\mathbf{d}}$ & $16.0^{\mathbf{d}}$ & $17.0^{\mathbf{d}}$ & $84.0^{\mathbf{f}}$ & $\mathrm{G}$ \\
GFDP3 & $19.0^{\mathbf{b}}$ & $19.0^{\mathbf{b}}$ & $18.0^{\mathbf{c}}$ & $18.0^{\mathbf{c}}$ & $19.0^{\mathbf{b}}$ & $93.0^{\mathbf{d}}$ & $\mathrm{V}$ \\
GFDP4 & $18.5^{\mathbf{b}}$ & $18.5^{\mathbf{b c}}$ & $17.5^{\mathbf{c}}$ & $17.5^{\mathbf{c}}$ & $18.0^{\mathbf{c}}$ & $90.0^{\mathbf{e}}$ & $\mathrm{V}$ \\
GFDP5 & $20.0^{\mathbf{a}}$ & $19.0^{\mathbf{b}}$ & $19.0^{\mathbf{b}}$ & $18.0^{\mathbf{c}}$ & $20.0^{\mathbf{a}}$ & $96.0^{\mathbf{c}}$ & $\mathrm{V}$ \\
\hline L.S.D. & $\mathbf{0 . 7 2 1 8}$ & $\mathbf{0 . 8 1 3 9}$ & $\mathbf{0 . 5 7 2 3}$ & $\mathbf{0 . 5 7 2 3}$ & $\mathbf{0 . 5 1 0 4}$ & $\mathbf{1 . 5 8 8 5}$ & \\
\hline
\end{tabular}

Each value with the same column is followed by the same letters is not significant different at level of 0.05 . 90-100 Very Good (V).80-89 Good (G).70-79 Satisfactory (S).Less Than 70 Questionable (Q).

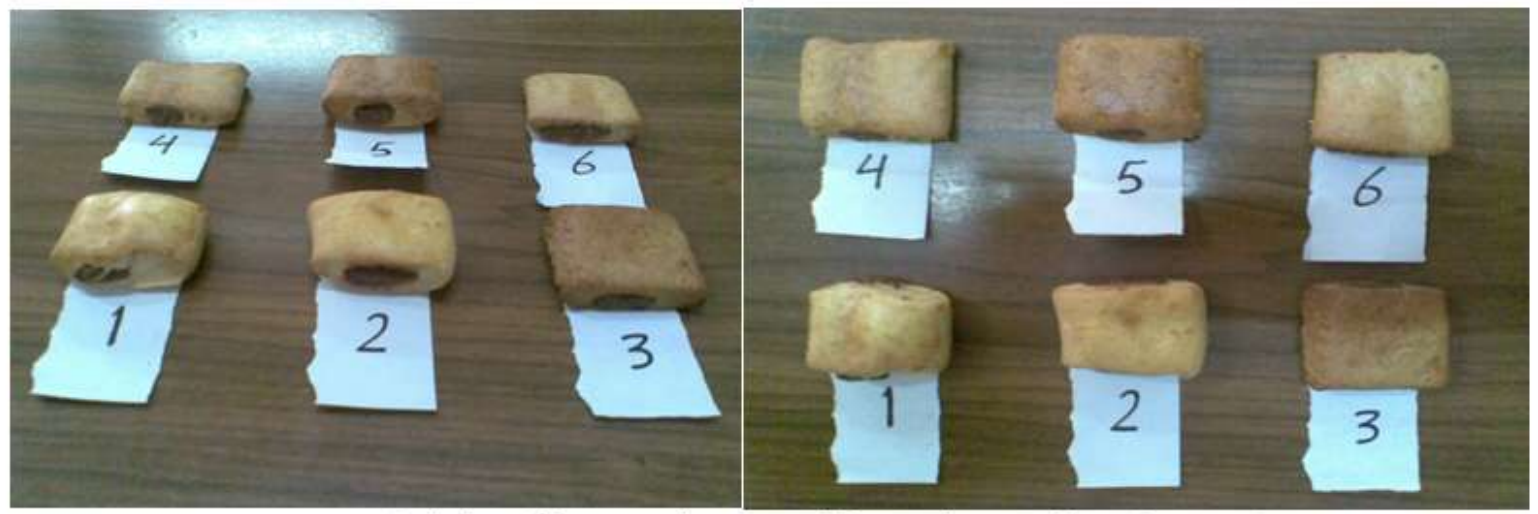

Fig (1):Different shapes of free gluten date bars pies.

$1=100 \%$ Wheat flour ( $72 \%$ ext.).

$2=20 \%$ Puree Potato $+5 \%$ Corn starch $+75 \%$ White rice flour.

$3=20 \%$ Puree Potato $+5 \%$ Corn starch $+75 \%$ Quinoa flour.

$4=20 \%$ Puree Potato $+30 \%$ Corn starch $+25 \%$ White rice flour $+25 \%$ Quinoa flour.

$5=20 \%$ Puree Potato $+5 \%$ Corn starch $+25 \%$ White rice flour $+50 \%$ Quinoa flour.

$6=20 \%$ Puree Potato $+5 \%$ Corn starch $+50 \%$ White rice flour $+25 \%$ Quinoa flour.

Table 7.Physical properties of producedglutenfree date bars pies (GFDP).

\begin{tabular}{cccccc}
\hline Treatment & $\begin{array}{c}\text { Moisture } \\
(\%)\end{array}$ & $\begin{array}{c}* \text { Weight } \\
(\mathrm{gm})\end{array}$ & $\begin{array}{c}* \text { Height } \\
(\mathrm{Cm})\end{array}$ & $\begin{array}{c}* \text { Volume } \\
\left(\mathrm{Cm}^{3}\right)\end{array}$ & $\begin{array}{c}\text { Specific volume } \\
\left(\mathrm{Cm}^{3} / \mathrm{gm}\right)\end{array}$ \\
\hline Control & 17.98 & 16.14 & 1.8 & 37 & 2.29 \\
GFDP 1 & 18.31 & 16.19 & 1.6 & 35 & 2.16 \\
GFDP2 & 18.93 & 16.50 & 1.4 & 33 & 2.00 \\
GFDP3 & 18.35 & 16.22 & 1.4 & 33 & 2.03 \\
GFDP4 & 18.82 & 16.36 & 1.4 & 33 & 2.02 \\
\hline GFDP5 & 18.40 & 16.25 & 1.6 & 35 & 2.15 \\
\hline
\end{tabular}

*For one parts. 
Chemical composition and caloric value of produced gluten free cracker (GFC):

Data in Table (8) show that, theall samples of GFC containing quinoa flour had the highest value of protein, fat, ash and dietary fiber contents and the lowest value of digestible carbohydrate and total energy compared with the GFC1 sample. All samples of GFC (except the GFC1) had protein content ranged from $6.44-11.10 \%$, fat $8.99-10.47 \%$, ash $4.08-5.34 \%$, dietary fiber $4.58-7.17 \%$, digestible carbohydrate $65.92-75.91 \%$ and total energy 402.31 $410.31 \mathrm{~K}$.cal, while the GFC1 had protein $6.29 \%$, fat $8.49 \%$, ash $3.55 \%$, dietary fiber $3.85 \%$, digestible carbohydrate $77.82 \%$ and total energy 412.85 K.cal. The rate of decrease in total caloric for samples was ranged from 1.44 to $3.96 \%$ compared with the control sample. Also, data in the same table show that the all samples ofGFC which containing quinoa flour had the highest values of minerals content (i.e., Iron, zinc, calcium, magnesium potassium, cupper and phosphors)and vitamins contents i.e., Thiamin $\left(\mathrm{B}_{1}\right)$ Riboflavin $\left(\mathrm{B}_{2}\right)$, Pyridoxine $\left(\mathrm{B}_{6}\right)$, Foliate $\left(\mathrm{B}_{9}\right), \mathrm{A}$ and $\mathrm{E}$ compared with the GFDP1 and control samples. Hence,GFC which containing quinoa flour are favorable than the GFC1sample because of their high content of important minerals and vitamins which depend upon the levels of quinoa flour substitution. These results are confirmed with those obtained by Jancurovaet al. (2009),Leeet al.(2009)and Doweidar-MonaandKamel (2011).

Table 8.Chemical composition of produced glutenfree cracker (GFC)(g/100g sample on dry weight basis).

\begin{tabular}{|c|c|c|c|c|c|c|}
\hline \multirow[t]{2}{*}{ Components \% } & \multirow[t]{2}{*}{ Control } & \multicolumn{5}{|c|}{ GFC blends } \\
\hline & & 1 & 2 & 3 & 4 & 5 \\
\hline Protein & 10.52 & 6.29 & 11.10 & 6.44 & 9.49 & 7.90 \\
\hline Fat & 8.77 & 8.49 & 10.47 & 8.99 & 9.81 & 9.15 \\
\hline Ash & 3.58 & 3.55 & 5.34 & 4.08 & 4.75 & 4.15 \\
\hline Dietary fiber & 2.66 & 3.85 & 7.17 & 4.58 & 6.06 & 4.96 \\
\hline * Digestible carbohydrate & 74.47 & 77.82 & 65.92 & 75.91 & 69.89 & 73.84 \\
\hline Caloric value (K.cal/100g) & 418.89 & 412.85 & 402.31 & 410.31 & 405.81 & 409.31 \\
\hline $\begin{array}{c}\text { Rate of decreased for } \\
\text { total caloric }\end{array}$ & - & 1.44 & 3.96 & 2.05 & 3.12 & 2.29 \\
\hline \multicolumn{7}{|c|}{ Mineral mg/100gm } \\
\hline $\mathrm{Fe}$ & 1.17 & 0.53 & 9.85 & 3.93 & 7.28 & 3.91 \\
\hline $\mathrm{Zn}$ & 0.73 & 0.84 & 4.34 & 1.83 & 3.17 & 2.01 \\
\hline $\mathrm{Ca}$ & 26.68 & 25.43 & 87.67 & 44.22 & 66.93 & 46.18 \\
\hline $\mathrm{Mg}$ & 23.09 & 42.39 & 144.03 & 68.46 & 110.15 & 76.27 \\
\hline $\mathrm{K}$ & 106.19 & 220.48 & 696.73 & 361.34 & 537.98 & 379.23 \\
\hline $\mathrm{Cu}$ & 0.14 & 0.23 & 3.41 & 1.27 & 2.35 & 1.28 \\
\hline $\mathrm{P}$ & 106.77 & 103.27 & 278.53 & 140.89 & 220.10 & 161.69 \\
\hline \multicolumn{7}{|c|}{ Vitamins content } \\
\hline Thiamin $\left(\mathrm{B}_{1}\right)(\mathrm{mg} / 100 \mathrm{gm}$ & 0.12 & 0.18 & 0.35 & 0.20 & 0.29 & 0.23 \\
\hline $\begin{array}{l}\text { Riboflavin }\left(\mathrm{B}_{2}\right) \\
(\mathrm{mg} / 100 \mathrm{gm})\end{array}$ & 0.04 & 0.03 & 0.27 & 0.11 & 0.19 & 0.11 \\
\hline $\operatorname{Niacin}\left(B_{3}\right)(\mathrm{mg} / 100 \mathrm{gm})$ & 1.23 & 2.89 & 1.98 & 1.96 & 2.28 & 2.59 \\
\hline Pyridexine $\left(\mathrm{B}_{6}\right)(\mathrm{mg} / 100 \mathrm{gm})$ & 0.04 & 0.52 & 0.53 & 0.42 & 0.52 & 0.51 \\
\hline Folate $\left(B_{9}\right)(\mu \mathrm{g} / 100 \mathrm{gm})$ & 25.54 & 7.98 & 123.41 & 45.48 & 84.93 & 46.46 \\
\hline A $(\mu \mathrm{g} / 100 \mathrm{gm})$ & 31.31 & 31.30 & 52.21 & 38.28 & 45.24 & 38.29 \\
\hline $\mathrm{E}(\mathrm{mg} / 100 \mathrm{gm})$ & 0.01 & 1.49 & 4.53 & 2.28 & 3.44 & 2.33 \\
\hline
\end{tabular}


Sensory characteristics of produced gluten free cracker (GFC):

Data in Table (9) and Fig (2) it could be observed that all samples of produced GFC were highly accepted (V.good). The maximum acceptance in sensory characteristics of the produced GFC was obtained in GFC1 (100 score) followed by GFC5 (98.5 score) followed by GFC3 (97.5 score) compared with control sample (96.0 score).

Table 9.Sensory evaluation of produced gluten free cracker (GFC)

\begin{tabular}{cccccccc}
\hline Treatment & $\begin{array}{c}\text { General } \\
\text { appearance } \\
(20)\end{array}$ & $\begin{array}{c}\text { Odor } \\
(20)\end{array}$ & $\begin{array}{c}\text { Taste } \\
(20)\end{array}$ & $\begin{array}{c}\text { Color } \\
(20)\end{array}$ & $\begin{array}{c}\text { Crispy } \\
(20)\end{array}$ & $\begin{array}{c}\text { Total } \\
\text { score } \\
(100)\end{array}$ & Acceptance \\
\hline Control & $19.0^{\mathbf{b}}$ & $20.0^{\mathbf{a}}$ & $19.0^{\mathbf{b}}$ & $18.0^{\mathbf{c}}$ & $20.0^{\mathbf{a}}$ & $96.0^{\mathbf{c}}$ & $\mathrm{V}$ \\
GFC1 & $20.0^{\mathbf{a}}$ & $20.0^{\mathbf{a}}$ & $20.0^{\mathbf{a}}$ & $20.0^{\mathbf{a}}$ & $20.0^{\mathbf{a}}$ & $100.0^{\mathbf{a}}$ & $\mathrm{V}$ \\
GFC2 & $18.0^{\mathbf{b c}}$ & $19.0^{\mathbf{b}}$ & $16.0^{\mathbf{d}}$ & $18.0^{\mathbf{c}}$ & $19.0^{\mathbf{b}}$ & $90.5^{\mathbf{e}}$ & $\mathrm{V}$ \\
GFC3 & $19.0^{\mathbf{b}}$ & $20.0^{\mathbf{a}}$ & $19.0^{\mathbf{b}}$ & $20.0^{\mathbf{a}}$ & $19.5^{\mathbf{a b}}$ & $97.5^{\mathbf{b}}$ & $\mathrm{V}$ \\
GFC4 & $18.0^{\mathbf{c}}$ & $20.0^{\mathbf{a}}$ & $18.0^{\mathbf{c}}$ & $19.0^{\mathbf{b}}$ & $19.5^{\mathbf{a b}}$ & $94.5^{\mathbf{d}}$ & $\mathrm{V}$ \\
GFC5 & $20.0^{\mathbf{a}}$ & $20.0^{\mathbf{a}}$ & $19.0^{\mathbf{b}}$ & $20.0^{\mathbf{a}}$ & $19.5^{\mathbf{a b}}$ & $98.5^{\mathbf{b}}$ & $\mathrm{V}$ \\
\hline L.S.D. & $\mathbf{0 . 6 5 1 4}$ & $\mathbf{0 . 2 7 2 8}$ & $\mathbf{0 . 7 1 1 5}$ & $\mathbf{0 . 5 9 1 5}$ & $\mathbf{0 . 5 2 4 8}$ & $\mathbf{1 . 4 4 8 8}$ & \\
\hline
\end{tabular}

Each value with the same column is followed by the same letters is not significant different at level of 0.05 . 90-100 Very Good (V).80-89 Good (G).70-79 Satisfactory (S).Less Than 70 Questionable (Q).

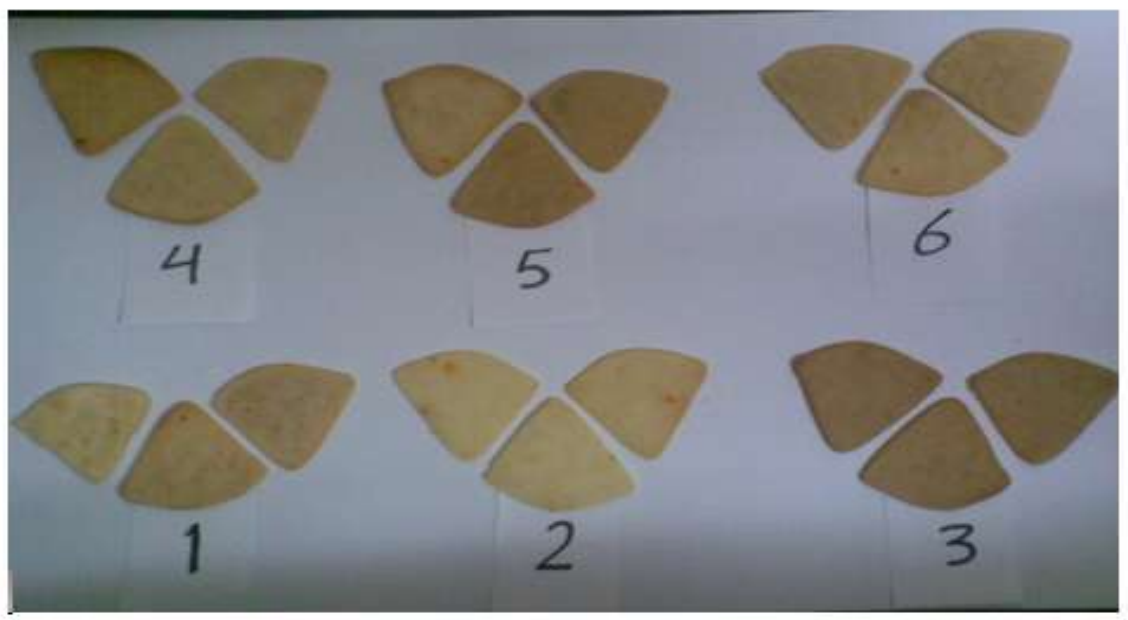

Fig (2): Different shapes of free glutencracker

$1=100 \%$ Wheat flour ( $72 \%$ ext.).

$2=20 \%$ Puree Potato $+5 \%$ Corn starch $+75 \%$ White rice flour.

$3=20 \%$ Puree Potato $+5 \%$ Corn starch $+75 \%$ Quinoa flour.

$4=20 \%$ Puree Potato $+30 \%$ Corn starch $+25 \%$ White rice flour $+25 \%$ Quinoa flour.

$5=20 \%$ Puree Potato $+5 \%$ Corn starch $+25 \%$ White rice flour $+50 \%$ Quinoa flour.

$6=20 \%$ Purno Potato $+5 \%$ Corn ctarch+ $50 \%$ Whito rirs flourt $25 \%$ Ouinna flour

Physical properties of produced gluten free cracker (GFC):

Table (10), show that all samples of GFC which containing quinoa had slight higher moisture content. It's ranged from 5.56 to $5.85 \%$ than the control $(5.35 \%)$ and GFC1 (5.40\%). Such increase in moisture content may be due to the increase levels of dietary fiber. Data in Table (10), show that, no effect was noticed in heightand volume of the
allGFCcompared with the control sample. While, specific volume were slight decreased by increased the substitution levels from 25 to $75 \%$ for quinoa flour. On the other hand the weights of GFC were slight increased by increased the substitution levels from 25 to $75 \%$ for quinoa flour. The increase of GFC weights may be due to the increased water absorption with the higher level of quinoa flour. 
Table 10.Physical properties of producedglutenfree cracker (GFC).

\begin{tabular}{cccccc}
\hline Treatment & $\begin{array}{c}\text { Moisture } \\
(\%)\end{array}$ & $\begin{array}{c}* \text { Weight } \\
(\mathrm{gm})\end{array}$ & $\begin{array}{c}* \text { Height } \\
(\mathrm{mm})\end{array}$ & $\begin{array}{c}* \text { Volume } \\
\left(\mathrm{Cm}^{3}\right)\end{array}$ & $\begin{array}{c}\text { Specific volume } \\
\left(\mathrm{Cm}^{3} / \mathrm{gm}\right)\end{array}$ \\
\hline Control & 5.35 & 1.57 & 27 & 2.8 & 1.78 \\
GFC 1 & 5.40 & 1.63 & 27 & 2.6 & 1.60 \\
GFC2 & 5.85 & 1.96 & 27 & 2.6 & 1.33 \\
GFC3 & 5.56 & 1.70 & 27 & 2.6 & 1.53 \\
GFC4 & 5.77 & 1.82 & 27 & 2.6 & 1.43 \\
GFC5 & 5.68 & 1.75 & 27 & 2.6 & 1.49 \\
\hline
\end{tabular}

*Average of 10 group of biscuits (measurements/10).

Chemical composition and caloric value of produced gluten free biscuits (GFB):

Data in Table (11) show that, the all samples of GFB containing quinoa flour had the highest value of protein, fat, ash and dietary fiber contents and the lowest value of digestible carbohydrate and total energy compared with the GFB1 (no containing quinoa flour). All samples of GFB (except the GFB1) had protein content ranged from 4.93-7.83\%, fat $14.18-15.09 \%$, ash $2.37-3.13 \%$, dietary fiber 2.67 $4.20 \%$, digestible carbohydrate $69.75-75.85 \%$ and total energy 446.13- 450.74K.cal, while the GFB1sample had protein $4.40 \%$, fat $13.86 \%$, ash $2.06 \%$, dietary fiber $2.23 \%$, digestible carbohydrate $77.45 \%$ and total energy $452.14 \mathrm{~K} . \mathrm{cal}$.

The rate of decrease in total caloric for samples was ranged from 0.85 to $2.17 \%$ compared with the control sample.

Table 11. Chemical composition of produced gluten free biscuit (GFB)(g/100g sample on dry weight basis).

\begin{tabular}{|c|c|c|c|c|c|c|}
\hline \multirow[b]{2}{*}{ Components \% } & \multirow{2}{*}{ Control } & \multicolumn{5}{|c|}{ GFB blends } \\
\hline & & 1 & 2 & 3 & 4 & 5 \\
\hline Protein & 7.85 & 4.40 & 7.83 & 4.93 & 6.82 & 5.84 \\
\hline Fat & 14.14 & 13.86 & 15.09 & 14.18 & 14.69 & 14.27 \\
\hline Ash & 2.10 & 2.06 & 3.13 & 2.37 & 2.76 & 2.41 \\
\hline Dietary fiber & 1.57 & 2.23 & 4.20 & 2.67 & 3.55 & 2.88 \\
\hline * Digestible carbohydrate & 74.34 & 77.45 & 69.75 & 75.85 & 72.18 & 74.60 \\
\hline Caloric value (K.cal/100g) & 456.02 & 452.14 & 446.13 & 450.74 & 448.21 & 450.19 \\
\hline $\begin{array}{l}\text { Rate of decreased for } \\
\text { total caloric }\end{array}$ & - & 0.85 & 2.17 & 1.16 & 1.71 & 1.28 \\
\hline \multicolumn{7}{|c|}{ Mineral mg/100gm } \\
\hline $\mathrm{Fe}$ & 0.87 & 0.43 & 6.74 & 2.55 & 4.64 & 2.54 \\
\hline $\mathrm{Zn}$ & 0.58 & 0.60 & 2.68 & 1.19 & 1.99 & 1.29 \\
\hline $\mathrm{Ca}$ & 41.23 & 38.73 & 77.52 & 50.43 & 64.61 & 51.66 \\
\hline $\mathrm{Mg}$ & 16.92 & 24.04 & 84.36 & 39.40 & 64.15 & 44.04 \\
\hline $\mathrm{K}$ & 72.52 & 92.0 & 374.62 & 175.62 & 280.44 & 186.18 \\
\hline $\mathrm{Cu}$ & 0.09 & 0.11 & 2.00 & 0.73 & 1.37 & 0.74 \\
\hline $\mathrm{P}$ & 74.88 & 64.57 & 168.57 & 86.87 & 133.91 & 99.23 \\
\hline \multicolumn{7}{|c|}{ Vitamins content } \\
\hline Thiamin $\left(\mathrm{B}_{1}\right)(\mathrm{mg} / 100 \mathrm{gm}$ & 0.08 & 0.09 & 0.20 & 0.11 & 0.16 & 0.13 \\
\hline $\begin{array}{l}\text { Riboflavin }\left(B_{2}\right) \\
(\mathrm{mg} / 100 \mathrm{gm})\end{array}$ & 0.04 & 0.03 & 0.20 & 0.10 & 0.12 & 0.08 \\
\hline $\operatorname{Niacin}\left(B_{3}\right)(\mathrm{mg} / 100 \mathrm{gm})$ & 0.73 & 1.42 & 0.88 & 0.86 & 1.06 & 1.24 \\
\hline Pyridexine $\left(\mathrm{B}_{6}\right)(\mathrm{mg} / 100 \mathrm{gm})$ & 0.03 & 1.25 & 0.25 & 0.19 & 0.25 & 0.25 \\
\hline Folate $\left(B_{9}\right)(\mu \mathrm{g} / 100 \mathrm{gm})$ & 15.14 & 3.74 & 72.24 & 25.99 & 49.42 & 26.58 \\
\hline $\mathrm{A}(\mu \mathrm{g} / 100 \mathrm{gm})$ & 51.40 & 51.37 & 63.78 & 55.50 & 59.64 & 55.51 \\
\hline $\mathrm{E}(\mathrm{mg} / 100 \mathrm{gm})$ & 0.03 & 0.07 & 0.94 & 0.34 & 0.65 & 0.46 \\
\hline
\end{tabular}

Also, data in the same table showed that all samples of GFB which containing quinoa flour had the highest values in minerals content (i.e., Iron, zinc, calcium , magnesium, potassium, cupper and phosphors) and vitamins contents (i.e. $\mathrm{B}_{1}, \mathrm{~B}_{2}, \mathrm{~B}_{6}, \mathrm{~B}_{9}$, $\mathrm{A}$ and E)compared with the GFDP1 and control samples. Hence, GFC samples containing quinoa flour are favorable than the GFC1 because of their 
high content of important minerals and vitamins which depend upon the quinoa flour levels of substitution. These results are confirmed by those of Jancurovaet al (2009), Lee et al (2009) and Doweidar-MonaandKamel (2011).

\section{Sensory characteristics of produced gluten free biscuits (GFB):}

Gluten free biscuits samples were sensory evaluated and compared with the control (wheat biscuit) as shown in Table (12) and Fig (3) there were no significant differences among control andGFB1samples for the general appearance, odor and color. Also were no significant differences among control and GFB1, GFB3, GFB5 samples for odor. In general, it could be observed that all samples of GFB were highly accepted (very good), except the sample which containing quinoa flour at level $75 \%$ had lowest acceptance (good).

\section{Physical properties of produced gluten free biscuits (GFB):}

Data in Table (13) show that all samples of GFB which containing quinoa had slight higher moisture content. It's ranged from 4.54 to $4.85 \%$ than the control (4.26\%) and GFB1 (4.40). The increase in moisture content may be due to the levels of dietary fiber. Also, data in the same table show that, diameter, thickness, spread ratio, volume and specific volume in all samples of GFB resultant slight decreased by increasing the quinoa flour substitution from 25 to $75 \%$. The weights of GFB were slight increased by increasing the quinoa flour substitution from 25 to $75 \%$.

Table12.Sensory evaluation of produced gluten free biscuit (GFB).

\begin{tabular}{|c|c|c|c|c|c|c|c|}
\hline *Treatment & $\begin{array}{c}\text { General } \\
\text { appearance } \\
(20)\end{array}$ & $\begin{array}{l}\text { Odor } \\
(20)\end{array}$ & $\begin{array}{l}\text { Taste } \\
(20)\end{array}$ & $\begin{array}{l}\text { Color } \\
(20)\end{array}$ & $\begin{array}{c}\text { Crispy } \\
(20)\end{array}$ & $\begin{array}{l}\text { Total } \\
\text { score } \\
(100) \\
\end{array}$ & Acceptance \\
\hline Control & $20.0^{\mathbf{a}}$ & $20.0^{\mathrm{a}}$ & $20.0^{\mathbf{a}}$ & $20.0^{\mathbf{a}}$ & $20.0^{\mathrm{a}}$ & $100.0^{\mathbf{a}}$ & V \\
\hline GFB1 & $20.0^{\mathrm{a}}$ & $20.0^{\mathrm{a}}$ & $19.0^{\mathbf{b}}$ & $20.0^{\mathbf{a}}$ & $19.0^{\mathbf{b}}$ & $98.0^{\mathbf{b}}$ & V \\
\hline GFB2 & $17.0^{\mathrm{d}}$ & $19.0^{\mathrm{c}}$ & $17.0^{\mathrm{d}}$ & $17.0^{\mathbf{c}}$ & $18.0^{\mathrm{c}}$ & $88.0^{\mathrm{e}}$ & G \\
\hline GFB3 & $19.5^{\mathbf{a b}}$ & $20.0^{\mathrm{a}}$ & $19.0^{\mathbf{b}}$ & $18.0^{\mathbf{b}}$ & $19.0^{b}$ & $95.5^{\mathrm{c}}$ & $\mathrm{V}$ \\
\hline GFB4 & $18.0^{\mathrm{c}}$ & $19.5^{\mathbf{b}}$ & $18.0^{\mathbf{c}}$ & $18.0^{\mathbf{b}}$ & $18.5^{\mathbf{b c}}$ & $92.0^{d}$ & V \\
\hline GFB5 & $19.0^{\mathbf{b}}$ & $20.0^{\mathbf{a}}$ & $19.0^{\mathbf{b}}$ & $20.0^{\mathbf{a}}$ & $18.5^{\mathbf{b c}}$ & $96.5^{\mathrm{c}}$ & V \\
\hline L.S.D. & 0.7062 & 0.3761 & 0.9292 & 0.8453 & 0.6723 & 1.4616 & \\
\hline
\end{tabular}

Each value with the same column is followed by the same letters is not significant different at level of 0.05 . 90-100 Very Good (V).80-89 Good (G).70-79 Satisfactory (S).Less Than 70 Questionable (Q).

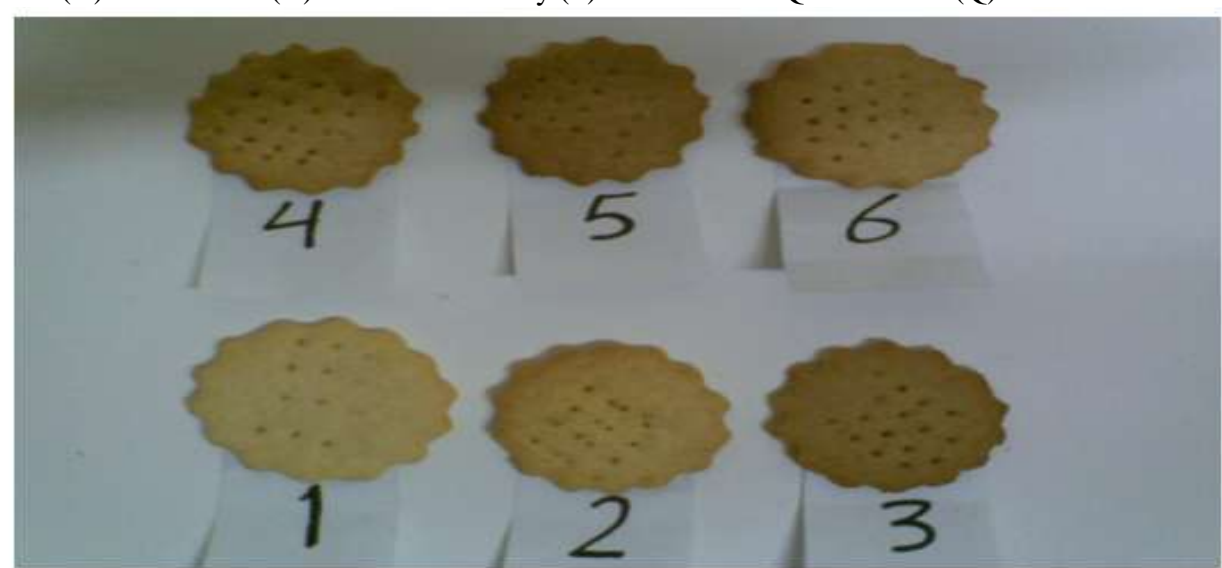

Fig (3): Different shapes of free gluten biscuit.

$1=100 \%$ Wheat flour ( $72 \%$ ext.).

$2=10 \%$ Puree Potato $15 \%$ Corn starch $+75 \%$ White rice flour.

$3=10 \%$ Puree Potato $+15 \%$ Corn starch $+75 \%$ Quinoa flour.

$4=10 \%$ Puree Potato $+40 \%$ Corn starch $+25 \%$ White rice flour $+25 \%$ Quinoa flour.

$5=10 \%$ Puree Potato $+15 \%$ Corn starch $+25 \%$ White rice flour $+50 \%$ Quinoa flour.

$6=10 \%$ Puree Potato $+15 \%$ Corn starch $+50 \%$ White rice flour $+25 \%$ Quinoa flour.

Table 13. Physical properties of produced gluten free biscuit (GFB). 


\begin{tabular}{cccccccc}
\hline Treatment & $\begin{array}{c}\text { Moisture } \\
\text { content }\end{array}$ & $\begin{array}{c}\text { *Diameter } \\
(\mathrm{D})\end{array}$ & $\begin{array}{c}\text { *Thickness } \\
(\mathrm{Tm})\end{array}$ & $\begin{array}{c}\text { Spread } \\
\text { ratio } \\
(\mathrm{mm})\end{array}$ & $\begin{array}{c}\text { *Volume } \\
(\mathrm{D} / \mathrm{T})\end{array}$ & $\begin{array}{c}\text { *Weight } \\
(\mathrm{gm})\end{array}$ & $\begin{array}{c}\text { Specific } \\
\text { volume } \\
\left(\mathrm{Cm}^{3} / \mathrm{gm}^{3}\right)\end{array}$ \\
\hline Control & 4.26 & 4.6 & 0.54 & 8.52 & 9.0 & 4.56 & 1.97 \\
GFB1 & 4.40 & 4.3 & 0.52 & 8.27 & 8.2 & 4.68 & 1.75 \\
GFB2 & 4.85 & 4.1 & 0.51 & 8.04 & 7.0 & 4.93 & 1.42 \\
GFB3 & 4.54 & 4.2 & 0.51 & 8.24 & 7.5 & 4.72 & 1.59 \\
GFB4 & 4.76 & 4.2 & 0.51 & 8.24 & 7.2 & 4.87 & 1.48 \\
\hline GFB5 & 4.64 & 4.3 & 0.52 & 8.27 & 8.1 & 4.80 & 1.69 \\
\hline
\end{tabular}

*Average of 10 group of biscuits (measurements/10).

Percentages of the recommended dietary allowances (\% RDA) are provided from produced product:

Recent studies have shown some nutritional inadequacies associated with the gluten-free diet (Thompson, 2000; Hllert et al., 2002; Dickey and Kearney, 2006). As the only treatment for coeliac disease remains the gluten-free diet, this raises a concern over the long-term health of individuals with celiac disease. In one study (Thompson, 2000) it was demonstrated that many of the gluten-free products were not enriched, fortified or naturally rich sources of folate, iron, or fibre. In another study (Thompson et al., 2005), it was demonstrated that $37 \%$ of males and $79 \%$ of females did not meet the recommended amount of grain servings per day. The USDA through the Food Guide Pyramid (USDA; accessed February 2009) recommends six to 11 servings from the grain/bread/starch group per day to meet the daily recommended intake for B complex vitamins and fiber. In the same study, most of the female participants did not meet recommended nutrient intakes. Of the female participants, only $44 \%$ met their recommended intake for iron, $46 \%$ for fiber, and $31 \%$ met their recommended intake of calcium.

The percentages of the recommended dietary allowances (\% RDA) are provided from $100 \mathrm{~g}$ of produced gluten free date bars pies, crackers and biscuits product for children and adults (males and females) are showed in Tables (14, 15 and 16), it could be observed that all values of \%RDA for protein, minerals (i.e., Iron, zinc, calcium , magnesium, cupper, phosphors and potassium)and vitamins contents (i.e., $\mathrm{B}_{1}, \mathrm{~B}_{2}, \mathrm{~B}_{3}, \mathrm{~B}_{6}, \mathrm{~B}_{9}, \mathrm{~A}$ and $\mathrm{E}$ ) and dietary fiber were increasing in all produced gluten free products (date bars pies, crackers and biscuits) by increase substitution levels of quinoa flour from 25 to $75 \%$.

\section{Economic evaluation:}

Cost production of the tested gluten free bakery products were calculated and tabulated in Table (17), it could be noticed that the production cost increased in all producedgluten free products (date bars pies , crackersand biscuits)compared with the control sample by increasing the levels substitution of quinoa flour. The rate of production cost was increase from 16.05 to $21.18 \%$ for gluten free date bars pies, from 12.32 to $17.05 \%$ for gluten free crackers and from 2.86 to $4.58 \%$ for gluten free biscuits.

\section{Conclusion}

From this study it can concluded that inclusion of germinated quinoa flour increased the nutrient profile of the gluten free dietary pattern. 
Table 14. Percentage of the RDA for some nutrient provided from $100 \mathrm{~g}$ of Gluten-Free products for children.

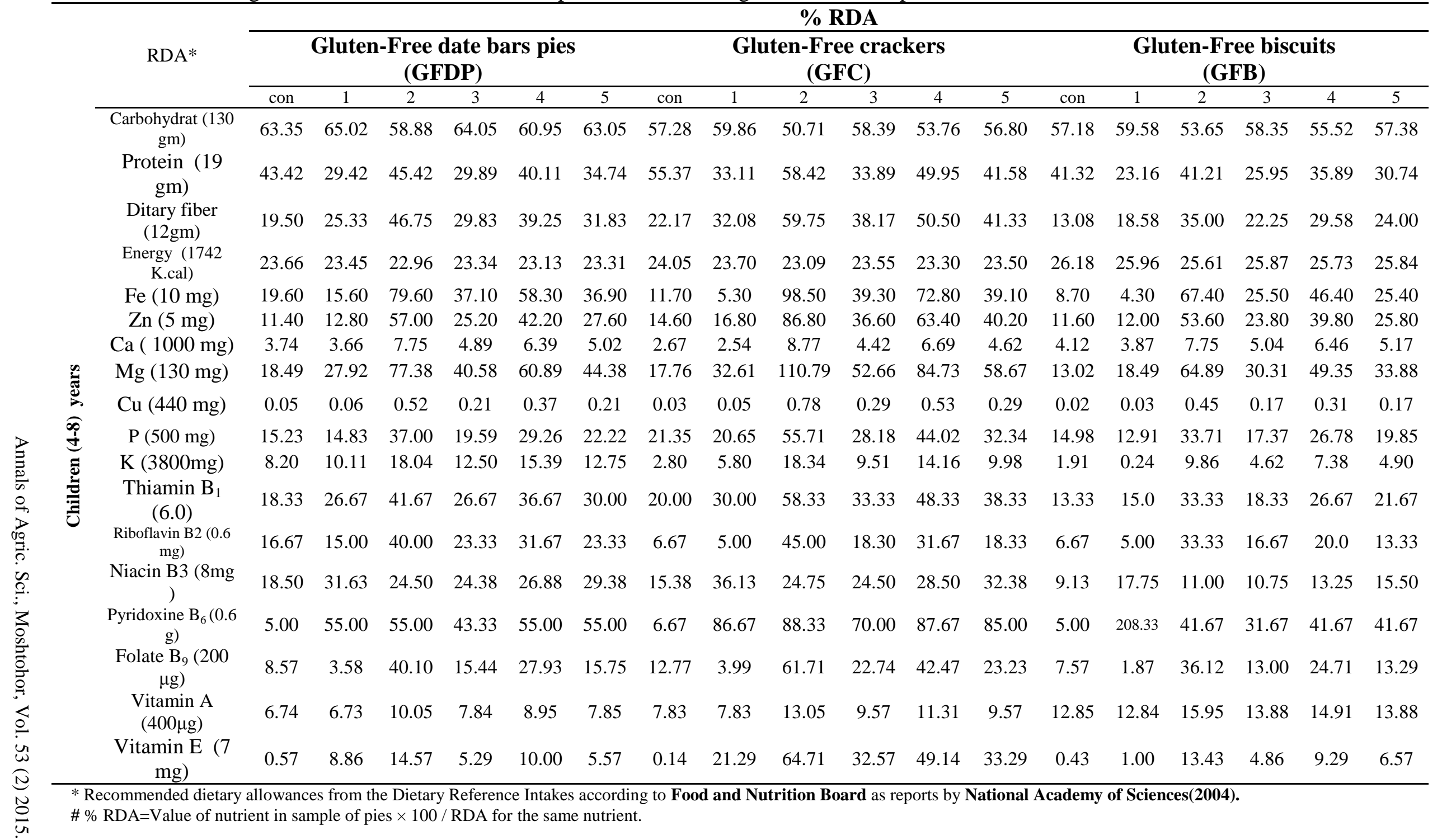


Table 15. Percentage of the RDA for some nutrient provided from 100g of Gluten-Free products for males.

\begin{tabular}{|c|c|c|c|c|c|c|c|c|c|c|c|c|c|c|c|c|c|c|c|}
\hline & \multirow{3}{*}{$\mathrm{RDA}^{*}$} & \multicolumn{18}{|c|}{ \% RDA } \\
\hline & & \multicolumn{6}{|c|}{$\begin{array}{c}\text { Gluten-Free date bars pies } \\
\text { (GFDP) }\end{array}$} & \multicolumn{6}{|c|}{$\begin{array}{c}\text { Gluten-Free crackers } \\
\text { (GFC) }\end{array}$} & \multicolumn{6}{|c|}{$\begin{array}{c}\text { Gluten-Free biscuits } \\
\text { (GFB) }\end{array}$} \\
\hline \multirow{19}{*}{ 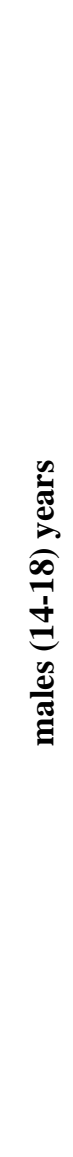 } & & Con. & 1 & 2 & 3 & 4 & 5 & Con. & 1 & 2 & 3 & 4 & 5 & Con. & 1 & 2 & 3 & 4 & 5 \\
\hline & $\begin{array}{l}\text { Carbohydrat }(130 \\
\text { gm) }\end{array}$ & 63.35 & 65.02 & 58.88 & 64.05 & 60.95 & 63.05 & 57.28 & 59.86 & 50.71 & 58.39 & 53.76 & 56.80 & 57.18 & 59.58 & 53.65 & 58.35 & 55.52 & 57.38 \\
\hline & Protein (52 gm) & 15.87 & 10.75 & 16.60 & 10.92 & 14.65 & 12.69 & 20.23 & 12.10 & 21.35 & 12.38 & 18.25 & 15.19 & 15.10 & 8.46 & 15.06 & 9.48 & 13.12 & 11.23 \\
\hline & $\begin{array}{l}\text { Ditary fiber }(25 \\
\mathrm{gm})\end{array}$ & 9.36 & 12.16 & 22.44 & 14.32 & 18.84 & 15.28 & 10.64 & 15.40 & 28.68 & 18.32 & 24.24 & 19.84 & 6.28 & 8.92 & 16.8 & 10.68 & 14.2 & 11.52 \\
\hline & $\begin{array}{l}\text { Energy }(3152 \\
\text { K.cal) }\end{array}$ & 13.07 & 12.96 & 12.69 & 12.90 & 12.78 & 12.88 & 13.29 & 13.10 & 12.76 & 13.02 & 12.87 & 12.99 & 14.47 & 14.34 & 14.15 & 14.30 & 14.22 & 14.28 \\
\hline & $\mathrm{Fe}(11 \mathrm{mg})$ & 17.82 & 14.18 & 72.36 & 33.73 & 53.00 & 33.55 & 10.64 & 4.82 & 89.55 & 35.73 & 66.18 & 35.55 & 7.91 & 3.91 & 61.27 & 23.18 & 42.18 & 23.09 \\
\hline & $\mathrm{Zn}(11 \mathrm{mg})$ & 5.18 & 5.82 & 25.91 & 11.45 & 19.18 & 12.55 & 6.64 & 7.64 & 39.45 & 16.64 & 28.82 & 18.27 & 5.27 & 5.45 & 24.36 & 10.82 & 18.09 & 11.73 \\
\hline & $\mathrm{Ca}(1300 \mathrm{mg})$ & 2.87 & 2.81 & 5.96 & 3.76 & 4.91 & 3.86 & 2.05 & 1.96 & 6.74 & 3.40 & 5.15 & 3.55 & 3.17 & 2.98 & 5.96 & 3.88 & 4.97 & 3.97 \\
\hline & $\operatorname{Mg}(410 \mathrm{mg})$ & 5.86 & 8.85 & 24.53 & 12.87 & 19.31 & 14.07 & 5.63 & 10.34 & 35.13 & 16.70 & 26.87 & 18.60 & 4.13 & 5.86 & 20.58 & 9.61 & 15.65 & 10.74 \\
\hline & $\mathrm{Cu}(890 \mathrm{mg})$ & 0.02 & 0.03 & 0.26 & 0.10 & 0.18 & 0.11 & 0.02 & 0.03 & 0.38 & 0.14 & 0.26 & 0.14 & 0.01 & 0.01 & 0.22 & 0.08 & 0.15 & 0.08 \\
\hline & $\mathrm{P}(1250 \mathrm{mg})$ & 6.09 & 5.93 & 14.80 & 7.84 & 11.85 & 8.89 & 8.54 & 8.26 & 22.28 & 11.27 & 17.61 & 12.94 & 5.99 & 5.17 & 13.49 & 6.95 & 10.71 & 7.94 \\
\hline & $\mathrm{K}(4700 \mathrm{mg})$ & 6.63 & 8.17 & 14.58 & 10.07 & 12.45 & 10.31 & 2.26 & 4.69 & 14.82 & 7.69 & 11.45 & 8.07 & 1.54 & 1.96 & 7.97 & 3.74 & 5.97 & 3.96 \\
\hline & $\begin{array}{l}\text { Thiamin } B_{1}(1.2 \\
\mathrm{mg})\end{array}$ & 9.17 & 13.33 & 20.83 & 13.33 & 18.33 & 15.00 & 10.00 & 15.00 & 29.17 & 16.67 & 24.17 & 19.17 & 6.67 & 7.5 & 16.67 & 9.17 & 13.33 & 10.83 \\
\hline & $\begin{array}{l}\text { Riboflavin } \\
\text { B2(1.3mg) }\end{array}$ & 7.69 & 6.92 & 18.46 & 10.77 & 14.62 & 10.77 & 3.08 & 2.31 & 20.77 & 8.46 & 14.62 & 8.46 & 3.08 & 2.31 & 15.38 & 7.69 & 9.23 & 6.15 \\
\hline & $\begin{array}{l}\text { Niacin B3 (16 } \\
\text { mg) }\end{array}$ & 9.25 & 15.81 & 12.25 & 12.19 & 13.44 & 14.69 & 7.69 & 18.06 & 12.38 & 12.25 & 14.25 & 16.19 & 4.56 & 8.88 & 5.50 & 5.38 & 6.63 & 7.75 \\
\hline & $\begin{array}{l}\text { Pyridoxine } \mathrm{B}_{6}(1.3 \\
\mathrm{mg})\end{array}$ & 2.31 & 25.38 & 25.38 & 20.00 & 25.38 & 25.38 & 3.08 & 40.0 & 40.77 & 32.31 & 40.0 & 39.23 & 2.31 & 96.15 & 19.23 & 14.62 & 19.23 & 19.23 \\
\hline & Folate $B_{9}(400 \mu \mathrm{g})$ & 4.29 & 1.79 & 20.05 & 7.72 & 13.96 & 7.88 & 6.39 & 2.00 & 30.85 & 11.37 & 21.23 & 11.62 & 3.79 & 0.94 & 18.06 & 6.50 & 12.36 & 6.65 \\
\hline & $\begin{array}{l}\text { Vitamin A (900 } \\
\mu \mathrm{g})\end{array}$ & 3.00 & 2.99 & 4.46 & 3.49 & 3.98 & 3.49 & 3.48 & 3.48 & 5.80 & 4.25 & 5.03 & 4.25 & 5.71 & 5.71 & 7.09 & 6.17 & 6.63 & 6.17 \\
\hline & $\begin{array}{l}\text { Vitamin E (15 } \\
\mathrm{mg})\end{array}$ & 0.27 & 4.13 & 6.80 & 2.47 & 4.67 & 2.60 & 0.07 & 9.93 & 30.20 & 15.20 & 22.93 & 15.53 & 0.20 & 0.47 & 6.27 & 2.27 & 4.33 & 3.07 \\
\hline
\end{tabular}

\# \% RDA=Value of nutrient in sample of pies $\times 100 /$ RDA for the same nutrient. 
Table 16. Percentage of the RDA for some nutrient provided from $100 \mathrm{~g}$ of Gluten-Free products for females.

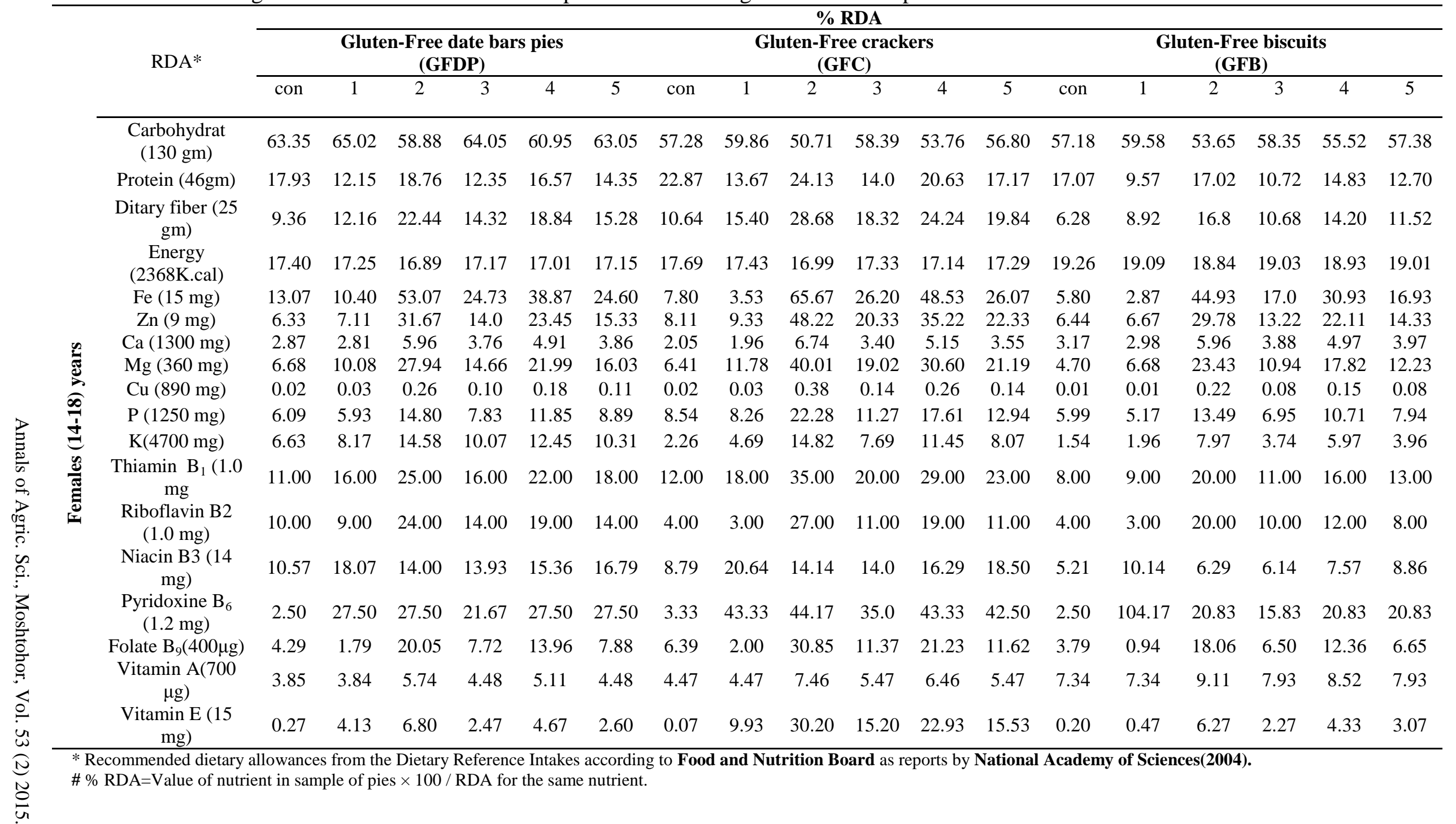


Table 17. Production cost of different types of Gluten-Free products for (1 K gm flour).

\begin{tabular}{|c|c|c|c|c|c|c|c|c|c|c|c|c|c|c|c|c|c|c|c|}
\hline \multirow{3}{*}{$\begin{array}{c}{ }^{*} \text { Raw } \\
\text { materials }\end{array}$} & & \multicolumn{18}{|c|}{ Gluten-Free products } \\
\hline & & \multicolumn{6}{|c|}{$\begin{array}{c}\text { Date bars Pies } \\
\text { (GFDP) }\end{array}$} & \multicolumn{6}{|c|}{$\begin{array}{c}\text { Crackers } \\
\text { (GFC) }\end{array}$} & \multicolumn{6}{|c|}{$\begin{array}{c}\text { Biscuits } \\
\text { (GFB) }\end{array}$} \\
\hline & & con & 1 & 2 & 3 & 4 & 5 & con & 1 & 2 & 3 & 4 & 5 & con & 1 & 2 & 3 & 4 & 5 \\
\hline blends & & 4.00 & 4.20 & 7.20 & 5.70 & 6.20 & 5.20 & 4.00 & 4.20 & 7.20 & 5.70 & 6.20 & 5.20 & 4.00 & 3.35 & 6.35 & 4.85 & 5.35 & 4.35 \\
\hline Ingredient & & 9.92 & 10.52 & 10.52 & 10.52 & 10.52 & 10.52 & 3.27 & 3.67 & 3.67 & 3.67 & 3.67 & 3.67 & 16.73 & 17.33 & 17.33 & 17.33 & 17.33 & 17.33 \\
\hline Total cost & & 13.92 & 14.72 & 17.72 & 16.22 & 16.72 & 15.72 & 7.27 & 7.87 & 10.87 & 9.37 & 9.87 & 8.87 & 20.73 & 20.68 & 23.68 & 22.18 & 22.68 & 21.68 \\
\hline $\begin{array}{l}\text { Cost } \\
\text { production }\end{array}$ & & 2.00 & 2.00 & 2.00 & 2.00 & 2.00 & 2.00 & 2.00 & 2.00 & 2.00 & 2.00 & 2.00 & 2.00 & 2.00 & 2.00 & 2.00 & 2.00 & 2.00 & 2.00 \\
\hline $\begin{array}{l}\text { Net cost for } \\
1 \mathrm{Kg} \text { flour }\end{array}$ & Cost & 15.92 & 16.72 & 19.72 & 18.22 & 18.72 & 17.72 & 9.27 & 9.87 & 12.87 & 11.37 & 11.87 & 10.87 & 22.73 & 22.68 & 25.68 & 24.18 & 24.68 & 23.68 \\
\hline $\begin{array}{l}\text { Net product } \\
\text { yield for } 1 \mathrm{Kg} \\
\text { flour }(\mathrm{Kg})\end{array}$ & & 1.775 & 1.780 & 1.815 & 1.784 & 1.799 & 1.787 & 1.020 & 1.059 & 1.210 & 1.130 & 1.163 & 1.137 & 1.880 & 1.846 & 2.007 & 1.922 & 1.960 & 1.925 \\
\hline $\begin{array}{l}\text { Net cost for } \\
1 \mathrm{Kg} \\
\text { product }\end{array}$ & & 8.97 & 9.39 & 10.87 & 10.21 & 10.41 & 9.92 & 9.09 & 9.32 & 10.64 & 10.06 & 10.21 & 9.56 & 12.09 & 12.28 & 12.80 & 12.58 & 12.59 & 12.30 \\
\hline $\begin{array}{l}\text { Rate of } \\
\text { increase in } \\
\text { cost }\end{array}$ & & - & 4.68 & 21.18 & 13.82 & 16.05 & 10.59 & - & 2.53 & 17.05 & 10.67 & 12.32 & 5.17 & - & 0.33 & 4.58 & 2.78 & 2.86 & 0.49 \\
\hline $\begin{array}{l}\text { *According } \\
\text { Net cost }(\mathrm{P}) \\
\mathrm{P}=\text { Egypt po }\end{array}$ & $\begin{array}{l}\text { o table (1 } \\
\text { or } 1 \mathrm{Kg} \\
\text { und }\end{array}$ & $\begin{array}{l}\text { the ca } \\
\text { luct = }\end{array}$ & $\begin{array}{l}\mathrm{f} \mathrm{GF} \\
0 \times \mathrm{N}\end{array}$ & P, tabl & in the & of $\mathrm{G}$ & dtabl & $\begin{array}{l}\text { in th } \\
.1 \mathrm{Ko}\end{array}$ & se of $C$ & & & & & & & & & & \\
\hline
\end{tabular}


References

A.A.C.C. (2002).Approved Method of American Association of Cereal Chemists.Approved Methods theA.A.C.C.published by the American Association of Cereal Chemists. $13^{\text {th }}$ Ed., Inc. St. Paul, Minnesota, USA.

A.O.A.C. (2005).Association of Official of Analytical Chemists, Official Methods of Analysis. $18^{\text {th }}$ Ed., Pub. by the A.O.A.C., Arlington, Virginia,2220USA.

Alvarez-Jubete, L., Wijngaard, H., Arendt, E.K., Gallagher, E., (2010).Polyphenol composition and in vitro antioxidant activity of amaranth, quinoa buckwheat and wheat as affected by sprouting and baking. Food Chemistry, 119: 770-778.

Alvarez-Jubete, L.; Arendt, E. K. and Gallagher, E. (2009a). Nutritive value and chemical composition of pseudocereals as gluten-free ingredients. Int. J. Food. Sci. Nutr., 60(suppl 4):240-257.

Alvarez-Jubete, L.; Holse, M.; Hansen, A.; Arendt, E. K. and Gallagher, E. (2009b).Impact of baking on the vitamin $E$ content of the pseudocereals amaranth, quinoa and buckwheat. Cereal Chem., 86(5):511-515.

Alvarez-Jubete, L.; Wijngaard, H. H.; Arendt, E. K. and Gallagher, E. (2010).Polyphenol composition and in vitro antioxidant activity of amaranth, quinoa and buckwheat as affected by sprouting and bread baking. Food Chem., 119:770-778.

Batifoulier, F.;Verny, M. A.;Besson, C.;Demigne, C. and Remesy, C. (2005). Journal of Chromatography B, 816:67-72.

Berti, C.; Ballabio, C.; Restani, P.; Porrini, M.; Bonomi, F. and Iametti, S. (2004).Immunochemical and Molecular Proteins inChenopodium quinoa. Cereal Chem., 81(2):275-277.

Bose, D. and Shams-Ud-Din, M. (2010).The effect of chickpea (Cicerarietinim) husk on the properties of cracker biscuits. J. Bangladesh Agril. Univ. 8(1):147-152.

Catassi, C., and Yachha, S. K. (2009). The epidemiology of celiac disease. In E. K. Arendt,\& F. Dal Bello (Eds.), The science of gluten-free foods and beverages (pp. 113).Minnesota, USA.: Academic Press.

Dickey, W. and Kearney, N. (2006). Overweight in celiac disease: prevalence, clinical characteristics, and effect of a gluten free diet. Am. J. Gastroenterol., 101: 2356-2359.

Doweidar-Mona, M. M. and Kamel, A. S. (2011). Using of quinoa for production of some bakery products (gluten-free). Egyptian J. of Nutrition XXVI (2):21-52.
FAO/WHO (1974).Energy and protein requirement.FAO nutrition meeting report series No.52 FAO, Rome.

Feighery, C. (1999).Fortnightly review - Coeliac disease.British Medical Journal, 319,236-239.

Gallagher, E. (2009).Gluten-free food science and technology. London, UK: John Wiley \& Sons.

Gallagher, E., Gormley, T. R. and Arendt, E. K. (2009). Recent advances in the formulation of gluten-free cereal-based products. Trends in Food Science \& Technology, 15:143-152.

Hareedylobna, A.M.; MahafauzeSanaa, A. and Kamel, A. S. (2009).Soybean-Quinoa drinks from newly introduced quinoa varieties in Egypt. Egyptian J. of Nutrtion. XXIIII (1):125-160.

Hllert, C.; Grant, C.;Grehn, S.;Gränno“, C.;Hulte'n, S.;Midhagen, G.;Stro“m, M.;Svensson, $H$. and Valdimarsson, $T$. (2002).Evidence of poor vitamin status in coeliac patients on a gluten-free diet for 10 years. Aliment.Pharmacol.Ther. 16:1333-1339.

Jancurova M.;Minarovičova $L$. andDandar A. (2009): Quinoa - a review. Czech J. Food Sci., 27: 71-79.

Johnston, S. D.; Rodgers, C. and Watson, R. G. P. (2004).Quality of life in screendetected and typical coeliac disease and the effect of excluding dietary gluten. European Journal of Gastroenterology \&Hepatology, 16: 1281-1286.

Konishi, Y.; Hirano, S.; Tsuboi, H. and Wada, M. (2004).Distribution of minerals in quinoa (Chenopodium quinoa Willd.) seeds.Biosci.,Biotechnol., Biochem., 68(1): 231234.

Koziol, M. (1992).Chemical composition and nutritional evaluation of Quinoa (Chenopodium quinoa, Willd). J. Food Comp. Anal.,5:35-68.

Kupper, C. (2005).Dietary guidelines and implementation for celiac disease.Gastroenterol., 128:S121-S127.

Lee, A. R.; Ng, D. L.; Dave,E.;Ciaccio,E.J. and Green, P. H. R. (2009). The effect of substituting alternative grains in the diet on the nutritional profile of the gluten-free diet. Journal of Human Nutrition and Dietetics, 22:359-363.

Ludvigsson, J. F., Osby, U., Ekbom, A. and Montgomery, S. M. (2007).Coeliac disease and risk of schizophrenia and other psychosis: A general population cohort study. Scandinavian Journal of Gastroenterology., 42: 179-185.

Marao ,L.M.;Payumo, E.M.; Aguinaldo, A.R. and Homma, S.(1988). Nutritional characteristics of weaning foods prepared from germinated cereals and legumes. J. Food Sci.. 53:1399-1405.

Moore, M. M.;Heinbockel, M.; Dockery, P.;Ulemer, H. M. and Arendt E. K. (2006). Network formation in gluten-free bread with application of transglutaminase. Cereal Chemistry.,83:28-36. 
Murray, J. A. (1999). The widening spectrum of celiac disease. American Journal of Clinical Nutrition, 69, 354-365.

Mustalahti, K.;Lohiniemi, S.; Collin, P.;Vuolteenaho, N.;Laippala, P. and Markku, M.(2002).Gluten free diet and quality of life in patients with screen-detected coeliac disease. Effective Clinical Practice, 5, 105-113.

Noll, G. N. (1996). High-performance liquid chromatographic analysis of retinal and retinol isomers. Journal of Chromatography A., 721:247-259.

Penarrieta, J. M.; Alvarado, J. A.; Akesson, B. and Bergenstahl, B. (2008). Total antioxidant capacity and content of flavonoid and other phenolic compounds in canihua (Chenopodiumpallidicaule); An Andean pseudocereal. Molec.Nutr. Food Res. 52:708717.

Pite`,M. (2008).Gluten IndustriaAlimentarcomogarantir a segurancaaonsumidoresceliacos.SeguracaeQuali dade Alimentar.pp:34-36.

Prosky, L.; Asp, N.; Furda, I..; Devries, J. W.; Schweizer, T. F. and Hardland, B. F. (1984).Determination of total dietary fiber in foods, food products and total diets, interlaboratory study. J. AOAC, 67:1044-1052.

Pyka, A. and Sliwiok, J. (2001). Chromatographic separation of tocopherols. Journal of Chromatography A, $935: 71-76$.

Ranhotra, G.; Gelroth, J. A.; Glaser, B. K.; Lorenzz.; K. J. and Johnson, D. L. (1993).Composition and protein nutritional quality of quinoa. Cereal Chem, 70:303-305.

Sategna-Guidetti, C.; Bruno, M.;Mazza, E.;Carlino, A.;Predebon, S. and Tagliabue, M. (1998).Autoimmune thyroid diseases and coeliac disease. European Journal of Gastroenterology \&Hepatology, 10, 927-931.

Sategna-Guidetti, C.;Grosso, S. B.;Grosso, S.;Mengozzi, G.;Aimo, G. and Zaccaria, T. (2000). The effects of 1-year gluten withdrawal on bone mass, bone metabolism and nutritional status in newly-diagnosed adult coeliac disease patients. Alimentary Pharmacology \& Therapeutics, 14, 35-43.

Silano, M., Volta, U., Mecchia, A. M., Dessi, M., Di Benedetto, R. and De Vincenzi, M.(2007). Delayed diagnosis of coeliac disease increases cancer risk. BMC Gastroenterology, 7/8. doi: 10.1186/1471-230X-7-8.

Snedecor, G. W. and Cochran, W. G. (1967).Statistical Methods $7^{\text {th }}$ ed.Iowa State Univ., Pres. Ames., Iowa. USA.

Stazi, A. V. and Mantovani, A. (2000). A risk factor for female fertility and pregnancy: celiac disease. Gynecological Endocrinology, 14: 454463.

Tengah, D., Wills, A. J. and Holmes, G. K. T. (2002). Neurological complications of coeliac disease. Postgraduate Medical Journal, 78, 393398.

Thompson, T. (1999). Thiamin, riboflavin, and niacin contents of the gluten free diet: is there cause for concern. J. Am. Diet Assoc., 99:858862.

Thompson, T. (2000).Folate, iron, and dietary fiber contents of the gluten free diet. J. Am. Diet. Assoc., 100: 1389- 1393.

Thompson, T.; Dennis, M.; Higgins, L.A.; Lee, A.R. and Sharrett, M.K. (2005). Gluten-free diet survey: are Americans with coeliac disease consuming recommended amounts of fiber, iron, calcium and grain foods. J. Hum. Nutr.Diet. 18, $163-169$.

USDA (United States Department of Agriculture); accessed February (2009).Food Guide Pyramid, http://fnic.nal.usda.gov/nal -display (accessed February 2009).

Valencia, S.; Svanberg, U.; Sandberg, A. and Ruales, J. (1999).Processing of quinoa (Chenopodium Quinoa, Willd.): effects on invitro iron availability and phytate hydrolysis. International Journal of Food Sciences and Nutrition, 50:203-211.

Valencia-Chamorro, S.A. (2003): Quinoa. In: Caballero B.: Encyclopedia of Food Science and Nutrition, Vol. 8. Academic Press, Amsterdam: 4895-4902. 


\title{
إعداد وتقييم مخبوزات خالية من الجلوتين بإستخدام الكينوا المنبتة
}

\author{
منى محمود محمد دويدار ' ، ثناء عبد السلام محمد عامر '،فاطمة محمد إبراهيم شاهين'، عمرو سعد شمس2 \\ 1- فسم بحوث الخبز والعجائن الغذائية - معهز بحوث تكنولوجيا الأغذية- مركز البحوث الزراعية- الجيزة. \\ 2- قسم بحوث التكثيف المحصولي - معهد بحوث المحاصيل الحقلية - مركز البحوث الزراعية- الجيزة.
}

\section{الملخص العربي}

هدفت هذه الدراسة إلي إنتاج بعض الدخبوزات الخالية من الجلوتين ومرتفعة القيمة الغذائية والحيوية ومتثابهة في خواصها الحسية لمثنلاتها من

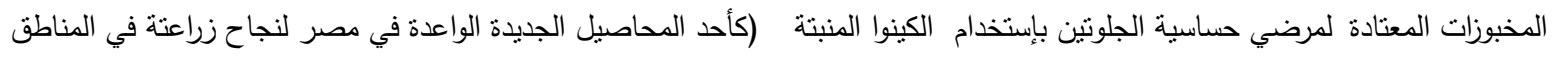

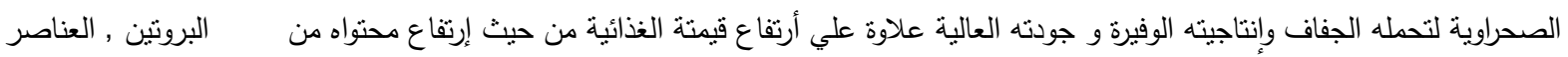

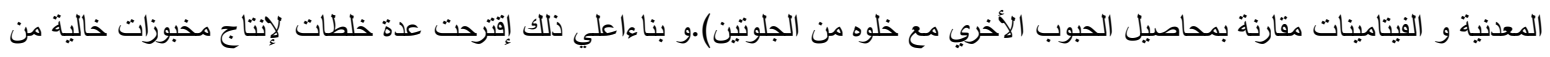

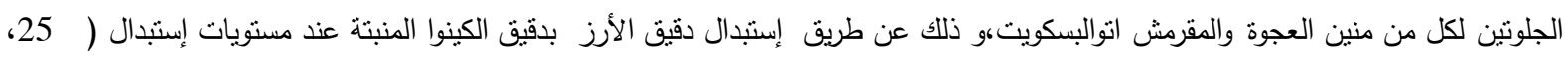

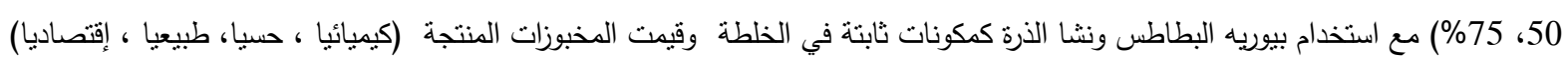

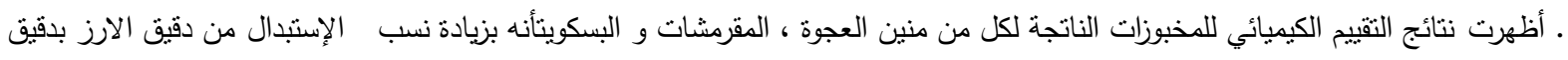

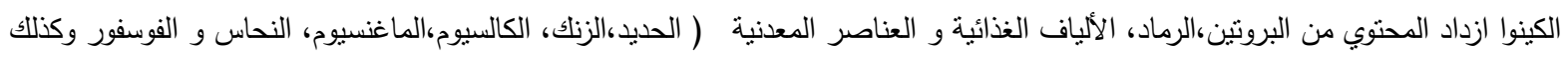

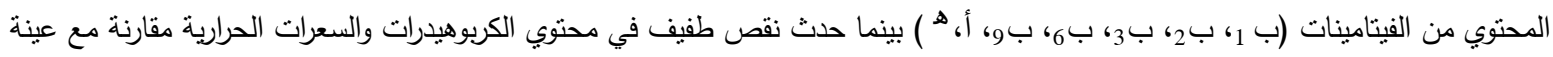

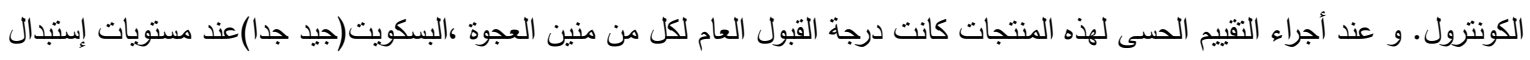

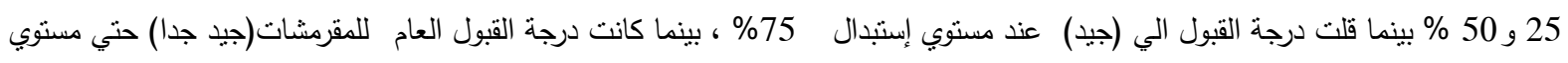

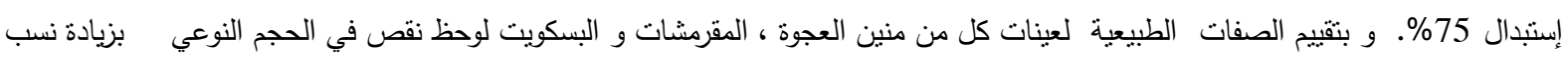

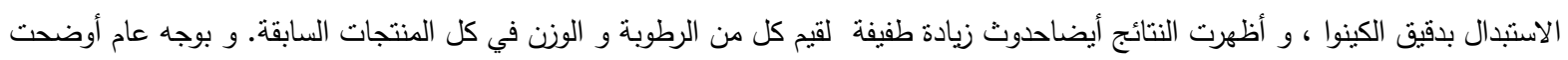

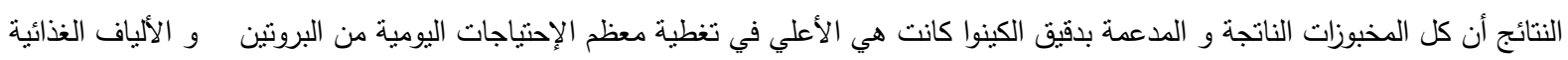

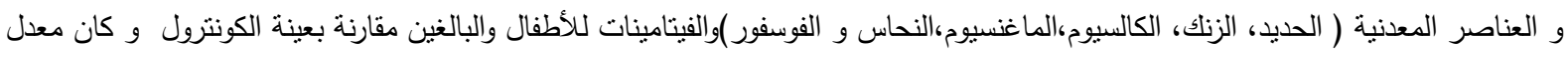

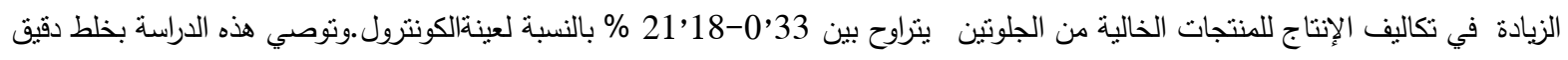

الكينوا مع دقيق الأرز لإنتاج مخبوزات خالية من الجلوتين وعالية القيمة الغذائية و الحيوية لمرضي حساسية الجلوتين ( Celiac disease) . 